\title{
Occurrence of Gentiana cruciata in dry grassland (Festuco-Brometea) in Kołaczyce (Strzyżowskie Foothills)
}

\author{
Tomasz Wójcik $^{1 *}$, Krystyna Towpasz ${ }^{2}$ \\ ${ }^{1}$ University of Rzeszow, Department of Agrobiology and Environmental Protection, \\ Zelwerowicza 4 St, 35-601 Rzeszów, Poland, \\ ${ }_{2}^{2}$ Jagiellonian University, Department of Plant Ecology, Kopernika 31, 31-501 Kraków, Poland \\ *e-mail: antomi7@wp.pl
}

Received: 11 October 2018 / Accepted: 5 February 2019

\begin{abstract}
The study presents the results of phytosociological studies of a plant community with Gentiana cruciata. The investigations were conducted in Kołaczyce, Wisłoka River valley (Strzyżowskie Foothills) in an area of $2000 \mathrm{~m}^{2}$. The study consisted in taking 22 phytosociological relevés, i.e. 2 relevés were taken in 1982 and 20 relevés in 2013, with the Braun-Blanquet method. The species population size was estimated at 2712 generative shoots. Gentiana cruciata grew in a community from the class Festuco-Brometea characterised by high floristic diversity and high species richness $\left(\mathrm{H}^{\prime}=3.24\right)$. The entire community comprised 91 species $(82$ species of vascular plants and 9 species of mosses), whereas 29-56 species (on average 45) were recorded in the relevés. The most numerous plants represented the class Festuco-Brometea (27 species) and Molinio-Arrhenatheretea (22 species). The highest abundance and constancy were exhibited by Centaurea scabiosa, Thymus pulegioides, Euphorbia cyparissias, Carex caryophyllea, and Gentiana cruciata from the class Festuco-Brometea as well as Origanum vulgare and Galium verum from the class Trifolio-Geranietea. The high natural value of the locality is indicated by the presence of protected species (Gentiana cruciata, Gentianella ciliata, Orobanche kochii) and rare species in the Carpathians (Thlaspi perfoliatum, Salvia verticillata, Carlina vulgaris, Brachypodium pinnatum, Viola hirta, Potentilla pusilla). After 30 years, the dry grassland with Gentiana cruciata is well preserved although it has been abandoned for 18 years. The appearance of shrubs (Prunus spinosa, Cornus sanguinea) indicates progressive secondary succession, which will lead in time to the development scrubs from the class Rhamno-Prunetea. Therefore, preservation of the area requires active protection measures.
\end{abstract}

Keywords: threatened species, protected plants, phytosociology, habitat preferences, Western Carpathians.

\section{Introduction}

Gentiana cruciata L. from the family Gentianaceae is a perennial plant reaching a height of $10-50(60) \mathrm{cm}$. It usually has an unbranched erect stem with dense foliage and internodes that are substantially shorter than the leaves. The $10 \mathrm{~cm}$ long and $2 \mathrm{~cm}$ wide stem leaves are elliptic to lanceolate, fused into a sheath at the base, with decussate

${ }^{*}$ corresponding author. arrangement. The tetramerous sessile flowers form a capitulum at the stem apex, and 1-3 flowers grow in the axils of the top leaves. The $2-3 \mathrm{~cm}$ long dirty-blue corolla has a tubular-campanulate shape (Piękoś-Mirkowa \& Mirek, 2006). The plant flowers between July and August. The flower is strongly protandrous. Gentiana cruciata is selfcompatible but produces very few seeds in the absence of pollination by bumblebees, hoverflies, and butterflies (Petanidou et al., 1995; Kozuharova et al., 2005). The fruit is a $2 \mathrm{~cm}$ long wingless capsule. The seeds are light (on average $0.134 \mathrm{mg}$ ) and reach a size of $0.67 \pm 0.12$ 
(0.5-1.25) mm (Kleyer et al., 2008; Alçitepe et al. 2017). The fruit contains on average 100 seeds (Kéry et al., 2001).

Gentiana cruciata has a Eurasian range covering southern and central Europe, Asia Minor, the Caucasus, Turkestan, and western Siberia (Hultén \& Fries, 1986; Zając \& Zając, 2009). In Poland, it grows in the mountains and highlands in the southern part of the country. Scattered localities of this species have been reported from the lower Oder and Vistula area, Mazury Lake District, Pomerania, and Wielkopolska regions (Zając \& Zając, 2001).

The species is a hemicryptophyte with high light and thermal requirements (Zarzycki et al., 2002). Most frequently, it grows on dry grasslands, dry meadows, pastures, sun-exposed slopes, and roadsides. It prefers calcium carbonate-containing clay or loess soils with neutral or alkaline $\mathrm{pH}(\mathrm{pH}$ 6.6-8.4). The species can be found on rendzinas and carbonate pararendzinas and less frequently on brown soils and chernozems (Babczyńska-Sendek \& Andrzejczuk, 1997; Piękoś-Mirkowa \& Mirek, 2006; Trąba et al., 2012). Gentiana cruciata is a species characteristic for the class Festuco-Brometea and, regionally, for the association Adonio-Brachypodietum pinnati (Matuszkiewicz, 2001).

The aim of the investigations was to assess the floristic and phytocoenotic diversity of a community with Gentiana cruciata and to determine the conservation status and transformation trends in this phytocoenosis. Additionally, the population size was estimated based on the number of generative shoots.

\section{Study area}

The investigations were conducted in Kołaczyce, Wisłoka River valley (Fig. 1). The area is part of Strzyżowskie Foothills, which belongs to the Outer Western Carpathians (Kondracki, 2011). The area of Strzyżowskie Foothills is located on flysch formations, which are characterised by low content of calcium carbonate. This is reflected in the local vegetation cover exhibiting a negligible proportion of dry habitat communities. In this respect, the Wisłoka River valley is an outstanding area, where the Krosno layers

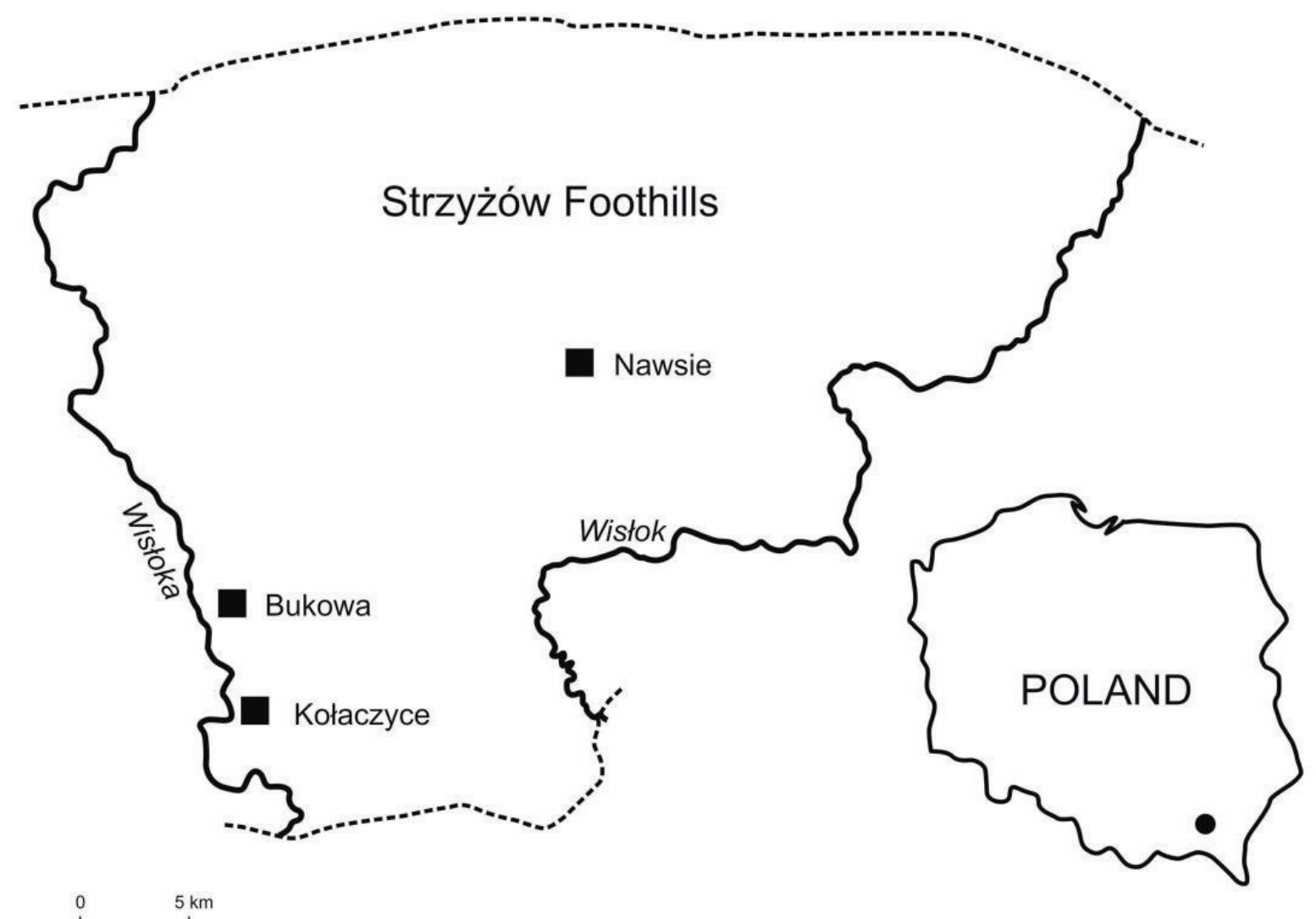

Figure 1. Localities of Gentiana cruciata in the Strzyżowskie Foothills 
contain inerlayers of laminated white limestone referred to as Jasło shales. The xerophilous and calciphilous vegetation developed on the shales is characterised by insular occurrence in this part of the Carpathians (Towpasz, 1990; Wójcik \& Ochyra, 2016). The study was conducted in an area located approximately $1 \mathrm{~km}$ north of the town centre. The observations were carried out on a plateau and slopes with varied exposure at an altitude of ca. $300 \mathrm{~m}$ a.s.l. The dry grassland with an area of ca. $2000 \mathrm{~m}^{2}$ was located near various types of plant communities characterised by mosaic-like spatial distribution. There were thermophilic scrubs from the class Rhamno-Prunetea, Larix decidua and Pinus sylvestris plantings, balks with shrub vegetation, fresh and dry meadows from the association Arrhenatheretum elatioris, pastures from the association Lolio-Cynosuretum, wastelands, and arable fields.

\section{Methods}

The studies were conducted with the Braun-Blanquet method (1964). Two phytosociological relevés with an area of $50 \mathrm{~m}^{2}$ and 20 relevés with an area of $25 \mathrm{~m}^{2}$ were taken in 1982 and 2013, respectively. The collected material was compiled in a phytosociological table (Table 1) by calculation of the constancy and cover coefficient. The affiliation of the species to syntaxonomic units was adopted from Matuszkiewicz (2001). The nomenclature of vascular plants and mosses followed those proposed by Mirek et al. (2002) and Ochyra et al. (2003), respectively. Protected species were enlisted based on the Regulation of the Minister of the Environment (Rozporządzenie, 2014). The species richness of the analysed community was calculated from the mean number of species per relevé and the total number of species, whereas the total diversity was assessed based on the Shannon-Wiener index (Pielou, 1974). Additionally, the size of the examined population was estimated based on the number of generative shoots.

\section{Results}

The Gentiana cruciata locality in Kołaczyce has been known for 150 years (Towpasz, 1987). In 1982, it has been verified again by Towpasz (1987), who estimated the population size at several tens of specimens. This wellpreserved locality has survived. 30 years ago Gentiana cruciata grew in the association Arrhenatheretum elatioris brizetosum mediae, in which the species characteristic of fresh meadows predominated (relevés 1 and 2, Table 1). The dry grassland with Gentiana cruciata developed on the plateau and the gently inclined $\left(1-15^{\circ}\right)$ slopes with varied (S, SW, N, NW) but mainly southern exposure. The community occupied an area of approximately $2000 \mathrm{~m}^{2}$ and exhibited distinct stratification. The highest layer was composed of shrubs with a cover up to $25 \%$. The herbaceous plant cover was in the range of $95-100 \%$. The lowest layer comprised mosses, which accounted for $5-50 \%$ of the cover. The community was characterised by high species richness and great floristic diversity, as indicated by the high Shannon-Wiener diversity index $\mathrm{H}^{\prime}=3.24$. The phytosociological relevés demonstrated from 29 to 56 species (on average 45). In the entire community, there were 91 taxa, including 82 vascular plant species and 9 moss species (Table 1). 


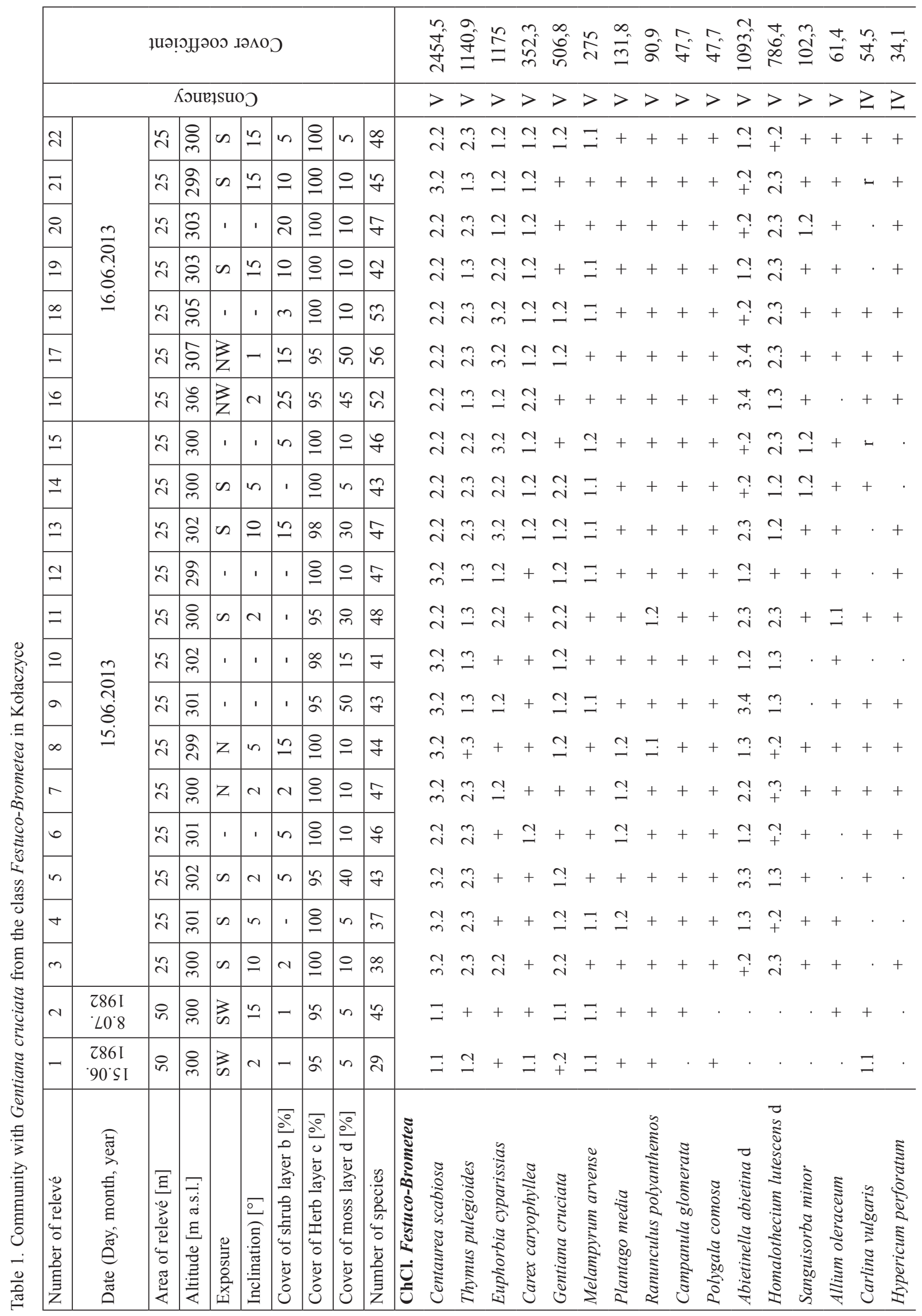




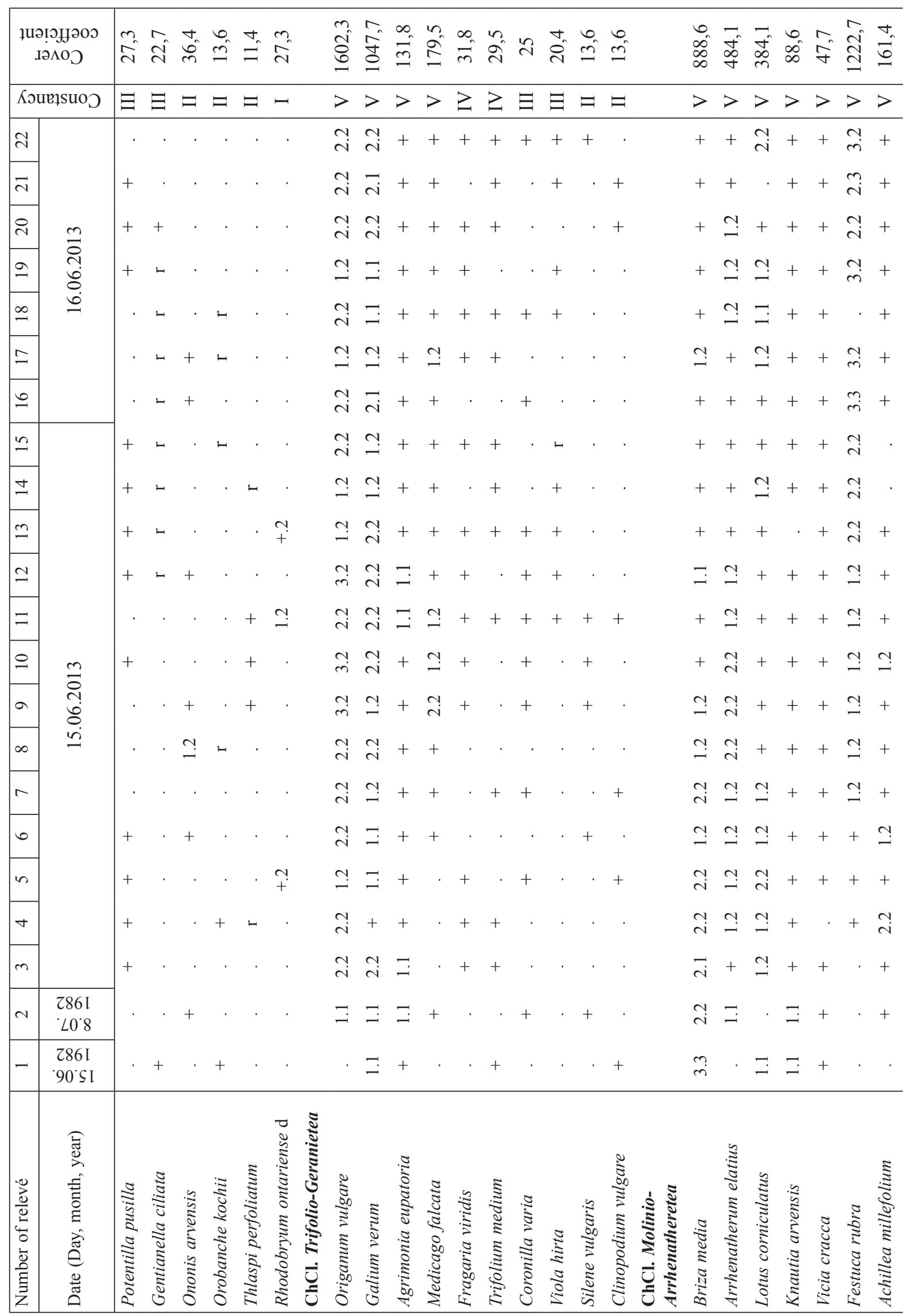




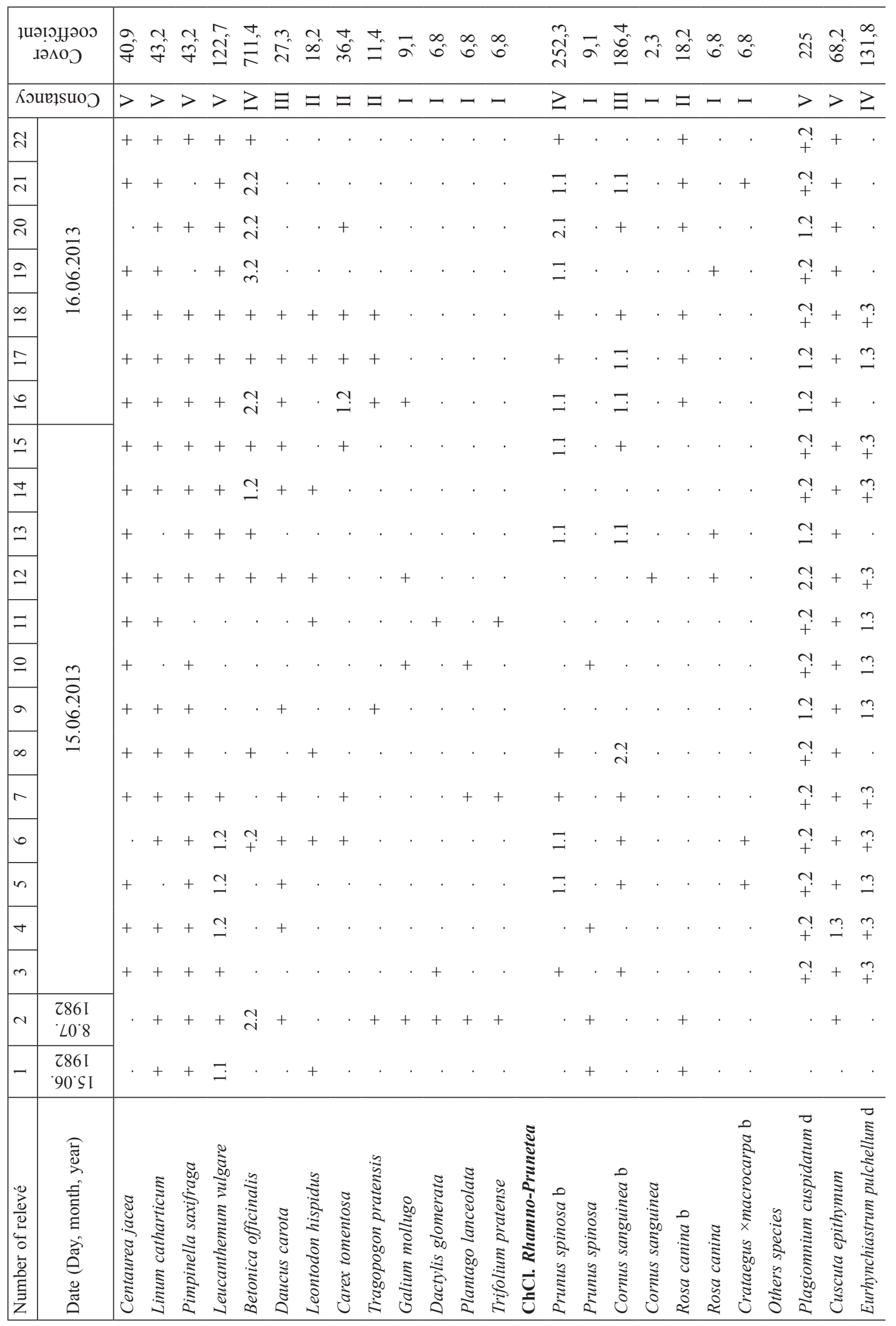




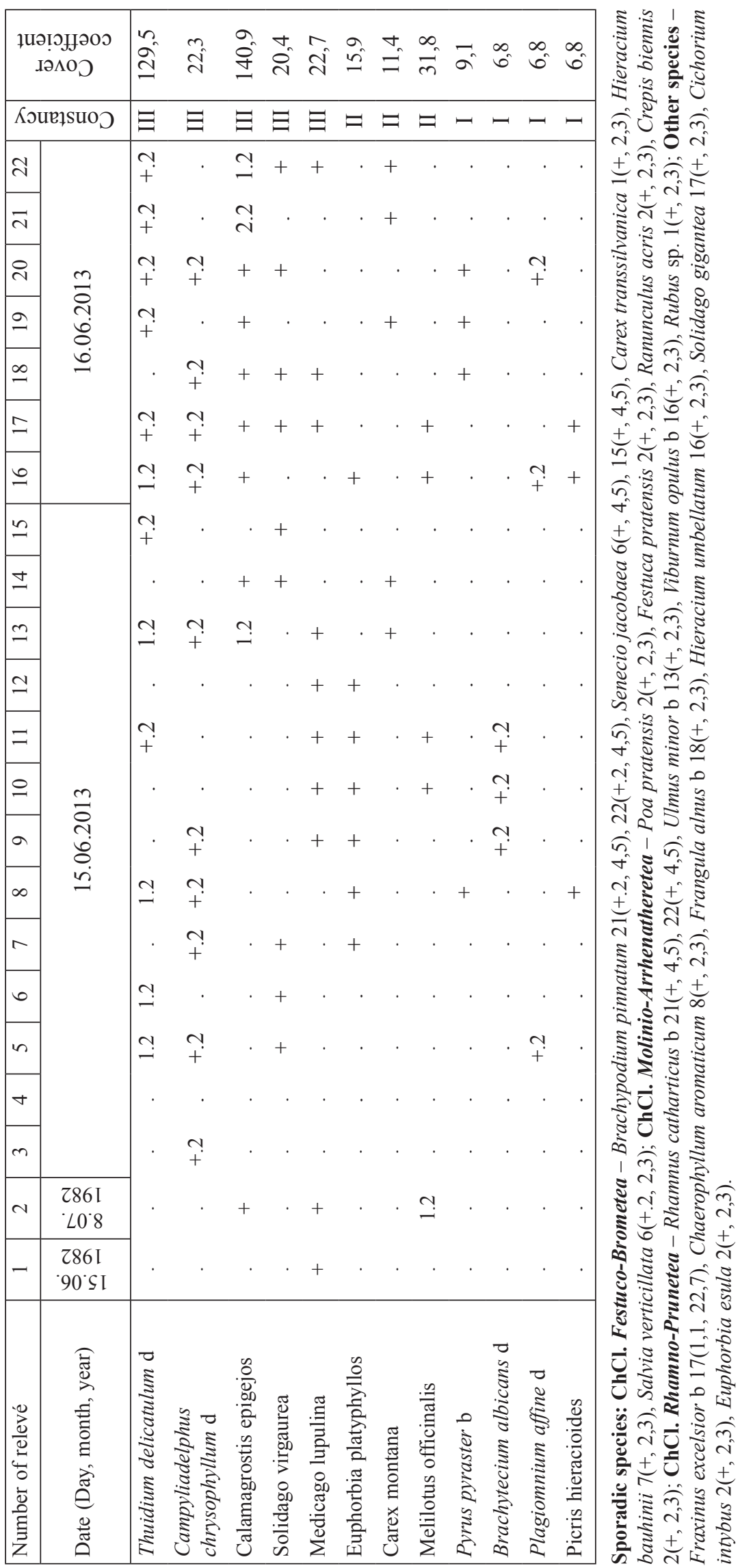


The class Festuco-Brometea was represented by 27 species, with 14 having constancy degree V. Great importance in the community structure and high abundance were achieved by Centaurea scabiosa, Thymus pulegioides, Euphorbia cyparissias, Carex caryophyllea, Gentiana cruciata, and Melampyrum arvense, which were the co-dominant species. From the class Trifolio-Geranietea, there were 10 characteristic species, with Origanum vugare and Galium verum reaching high coverage. The class Molinio-Arrhenathereta was represented by 24 species. Eleven of these species were characterised by the highest constancy degree, but a majority had low abundance and grew in small clusters. The exceptions were Briza media, Arrhenatherum elatius, Lotus corniculatus, Festuca rubra, and Betonica officinalis, which in some relevés constituted an important complement and achieved significant coverage in the phytocoenosis. The class Rhamno-Prunetea was represented by 8 species, but a majority of these species occurred sporadically, with the exception of Prunus spinosa and Cornus sanguinea. There were also 22 species with undetermined syntaxonomic affiliation.

The community with Gentiana cruciata exhibited high species diversity. There were no expansive or clearly dominant species. Noteworthy, there was a rich moss layer composed of 9 moss species, i.e. Rhodobryum ontariense, Abietinella abietina, Homalothecium lutescens, Plagiomnium cuspidatum, Eurhynchiastrum pulchellum, Thuidium delicatulum, Campyliadelphus chrysophyllum, Brachytecium albicans, and Plagiomnium affine. The high natural value of the locality was emphasised by the presence of protected species (Gentiana cruciata, Gentianella ciliata, Orobanche kochii) and rare species in the Carpathians (Thlaspi perfoliatum, Salvia verticillata, Carlina vulgaris, Brachypodium pinnatum, Viola hirta, Potentilla pusilla). Noteworthy was also the occurrence of a rare moss species Rhodobryum ontariense, which has been reported from only several localities in Poland (Wójcik \& Ochyra, 2016; Ellis et al., 2016).

The $\mathrm{pH}$ measurements from 1982 showed a value of 7.5 , which was also confirmed in 2013. In the first study period, regular grazing was carried out in the locality with Gentiana cruciata. In 2000, the land use was discontinued (information provided by the owner of the land), which resulted in a progressive process of succession. It is evidenced by the presence of scrub species from the class Rhamno-Prunetea, in particular Prunus spinosa and Cornus sanguinea. The Gentiana cruciata population is highly abundant and well preserved - it counts 2712 generative shoots. However, its further survival will require active protection measures (mowing, grazing) and introduction of monitoring.

\section{Discussion and conclusion}

Dry grasslands, whose occurrence is determined by the presence of calcium carbonate in the substrate, are extremely rare communities in the Polish Carpathians. To date, they have been described from e.g. the Pieniny Mountains (Kaźmierczakowa, 2004), Bukowskie Foothills (Trąba et al., 2012), and Przemyskie Foothills (Szczeblewska \& Janecki, 1999; Kucharzyk, 2010; Kucharzyk \& Szary, 2009; Trąba et al., 2012). The areas of Karpackie Foothills is characterised by calcium carbonate-poor flysch formations, hence the absence of well-developed dry grasslands Festuco-Brometea in this region. Investigations carried out in recent years have demonstrated the presence of small grassland stands on slopes and plateaus of river valleys developed on inerlayers of laminated white limestone called Jasło shales. Xerophilous vegetation stands have been reported from Strzyżowskie Foothills, i.e. Wielopolka River valley (Wójcik \& Piątek, 2015) and Wisłoka River valley (Wójcik \& Ochyra, 2016; Wójcik, 2018), and from Dynowskie Foothills (Ziaja \& Wójcik, 2014; Wójcik \& Ziaja, 2015). They are difficult to classify into lower syntaxonomic units due to the large proportion of xerothermic species from the class Festuco-Brometea, fringe species from the class Trifolio-Geranietea, and meadow species from the class Molinio-Arrhenatheretea. This indicates an intermediate nature of these communities.

The phytocoenosis observed in Kołaczyce has been described as a community from the class Festuco-Brometea. However, it should be emphasized that 30 years ago it was similar to the association Arrhenatheretum elatioris brizetosum mediae. Its xerothermic character is highlighted by the well-developed moss layer and the relatively small proportion of clumping grasses. The adjacent grassland stands with the rare moss species Rhodobryum ontariense (Wójcik \& Ochyra, 2016; Ellis et al., 2016), which comprised abundant Gentiana cruciata plants, were classified similarly. Besides Kołaczyce, Gentiana cruciata is present in two localities in Strzyżowskie Foothills (Fig. 1). In Nawsie, it grows on a slope descending to the Wielopolka River valley in the association Arhhenatheretum elatioris, which is characterised by a high drying degree and a large proportion of thermophilic species (Wójcik \& Piątek, 2015). In turn, in Bukowa, the analysed species occurs on steep slopes in the Wisłoka River valley in a community with Brachypodium pinnatum from the class Festuco-Brometea (Wójcik, 2018). In the neighbouring mesoregion, i.e. Dynowskie Foothills, Gentiana cruciata was noted sporadically in a fringe community from the class Trifolio-Geranietea (Ziaja \& Wójcik, 2014). In Bukowskie Foothills, it was present in community stands with Bromus erectus and in a community with Brachypodium pinnatum (Trąba et al., 2012). The species 
is more frequent in Przemyskie Foothills, where it was reported from a community with Brachypodium pinnatum (Szczeblewska \& Janecki, 1999; Kucharzyk, 2010; Trąba et al., 2012), association Arrhenatheretum elatioris brizetosum mediae (Barabasz-Krasny, 2011), and association Arrhenatheretum elatioris centauretosum scabiosae (Kucharzyk \& Szary, 2009). Besides the Foothills, Gentiana cruciata has been reported mainly from the Pieniny Mountains, where it grows in associations OriganoBrachypodietum (Kaźmierczakowa, 2004) and AnthyllidiTrifolietum montani (Kaźmierczakowa et al., 2004). The species grows in similar habitats on the other side of the Carpathians. In Slovakia, it is present in associations Scabioso ochroleucae-Brachypodietum pinnati, Polygalo majoris-Brachypodietum pinnati, and Carici albae-Brometum monocladi from the class Festuco-Brometea (Hegedüšová \& Škodová, 2014). In turn, in the Czech Republic, it is a diagnostic species for the association Anthoxantho odorati-Agrostietum tenuis from the alliance Cynosurion cristati (Chytrý, 2010).

Besides the Carpathian localities, phytocoenoses with the presence of Gentiana cruciata have been reported from the upland part of the country. In Wyżyna Śląska Upland, the species grows in floristically rich dry grasslands from the association Cirsio-Brachypodion (Babczyńska-Sendek \& Andrzejczuk, 1997), community with Bromus erectus, community Centaurea scabiosa-Agrimonia eupatoria, and association Adonio-Brachypodietum pinnati arrhenatheretosum (Babczyńska-Sendek, 2005). The community Centaurea scabiosa-Agrimonia eupatoria is most similar to the phytocoenosis present in Kołaczyce in terms of the floristic composition. In Wyżyna Krakowsko-Częstochowska Upland, Gentiana cruciata was found in dry grasslands from the class Festuco-Brometea (Babczyńska-Sendek et al., 2014). Localities from lowland regions have been reported as well. In Pomorze Zachodnie, Gentiana cruciata was reported from the association Adonio-Brachypodietum pinnati and from degraded grassland stands associated with meadows dominated by dry Arrhenatherum elatius and Calamagrostis epigejos (Piotrowska, 2010). In turn, in Pojezierze Chełmińskie, the species was found in dry grasslands from the class Festuco-Brometea, association Arrhenatheretum elatioris, and initial community from the classes Robinietea and Artemisietea vulgaris (Kamiński et al., 2018).

Gentiana cruciata usually grows in floristically rich communities. In the analysed locality, there were in total 91 species, and the phytosociological relevés showed 2956 species (on average 45). The results of this study are in good agreement with literature reports. 139 species were reported in the association Adonio-Brachypodietum pinnati and 15-42 (on average 31) were noted in relevés (Piotrowska, 2010). Similar results were presented by Trąba et al. (2012) in a community with Brachypodium pinna- tum and in a community with Bromus erectus. The former community comprised 197 species in total and there were 18-59 species (on average 31 ) in relevés. These values in the latter community were 103 and 25-43 (on average 33 ), respectively. Plant communities comprising the analysed species are characterised by a high Shannon-Wiener diversity index, as confirmed by the result for Kołaczyce $\left(\mathrm{H}^{\prime}=3.24\right)$. Similar values of this index were recorded in the community with Brachypodium pinnatum $\left(\mathrm{H}^{\prime}=3.22\right)$ and those noted in the community with Bromus erectus were slightly lower $\left(\mathrm{H}^{\prime}=2.87\right)$ (Trąba et al., 2012).

Investigations conducted by many authors indicate different sizes of Gentiana cruciata populations. In Switzerland and France, they range from 1 to 337 individuals, but most populations are small and do not exceed 12 individuals (Kéry et al., 2001). In Pomorze Zachodnie, the population size ranges from 30 to 111 individuals (Piotrowska, 2010), whereas the abundance of the species some localities in Wyżyna Śląska Upland is estimated at several thousand generative shoots (Babczyńska-Sendek \& Andrzejczuk, 1997). With its size of 2712 generative shoots, the locality in Kołaczyce represents a large population in comparison to the study reported by Kéry et al. (2001).

After 30 years of research, the dry grassland with Gentiana cruciata is well preserved; however, it has been abandoned for 18 years. The progressive secondary succession is evidenced by the appearance of shrubs (Prunus spinosa, Cornus sanguinea) accounting for $25 \%$ of coverage in some relevés. This will lead in time to the development scrubs from the class Rhamno-Prunetea, as indicated by other authors (Alard et al., 2005; Barabasz-Krasny, 2011; Dzwonko \& Loster, 2011; Kompała-Bąba \& Bąba, 2013). Intensive growth of shrubs is observed in close proximity to the analysed grassland. An additional threat is the afforestation of grass areas, e.g. in a surrounding area, where Pinus sylvestris and Larix decidua had been planted on the dry grassland. Further preservation of this valuable and rare phytocoenosis in the Carpathians requires active protection measures consisting in grazing or extensive mowing as well as removal of trees and shrubs (Bąba, 2003).

\section{Acknowledgments}

The authors are grateful to prof. dr hab. Ryszard Ochyra for identification of mosses, prof. dr hab. Elżbieta Kuta for identification of Viola hirta, and dr hab. Renata Piwowarczyk for identification of Orobanche kochii.

\section{References}

Alard D., Chabrerie O., Dutoit D., Roche P. \& Langlois E., 2005, Patterns of secondary succession in calcareous 
grasslands: can we distinguish the influence of former land uses from present vegetation data? Basic and Applied Ecology 6: 161-173.

Alçitepe E., Erken S., Gülbag F. \& Özzambak M.E., 2017, Remarks using the SEM method species seeds of Gentiana occurring in Turkey. Planta Daninha 35: 1-9.

Babczyńska-Sendek B. \& Andrzejczuk I., 1997, Gentiana cruciata L. in the neighbourhood of Tarnowskie Góry. Natura Silesiae Superioris 1: 33-42.

Babczyńska-Sendek B., 2005, Problemy fitogeograficzne i syntaksonomiczne kserotermów Wyżyny Śląskiej [Phytogeographic and syntaxonomic problems of the Silesian Upland xerotherms]. Wydawnictwo Uniwersytetu Śląskiego, Katowice.

Babczyńska-Sendek B., Błońska A. \& Skowronek I., 2014, New localities of Gentiana cruciata (Gentianaceae) in the Kraków-Częstochowa Upland. Fragmenta Floristica et Geobotanica Polonica 21(1): 67-76.

Barabasz-Krasny B., 2011, Zróżnicowanie roślinności i sukcesja wtórna na odłogach wielkopowierzchniowych Pogórza Przemyskiego [Vegetation differentiation and secondary succession on abandoned agricultural grand-areas in Przemyśl Foothills (South-Eastern Poland)]. Instytut Botaniki im. W. Szafera, Polska Akademia Nauk, Kraków.

Bąba W., 2003, Changes in the structure and floristic composition of the limestone grassland after cutting trees and shrubs and mowing. Acta Societatis Botanicorum Poloniae 72(1): 61-69.

Braun-Blanquet J., 1964, Pflanzensoziologie. Grundzüge der Vegetationskunde. Wien: Springer. (http://dx.doi. org/10.1007/978-3-7091-8110-2).

Chytrý M., (ed.), 2010, Vegetace České republiky. 1. Travinná a keříčková vegetace [Vegetation of the Czech Republic. 1. Grassland and Heathland Vegetation]. Academia, Praha.

Dzwonko Z. \& Loster S., 2011, Changes in species composition of an abandoned limestone grassland in relation to climatic conditions. Polish Journal of Ecology 59(4): 687-698.

Ellis L.T., Asthana A.K., Srivastava P., Omar I., Rawat K.K., Sahu V., Cano M.J., Costa D.P., Dias E.M., Dias Dos Santos N., Silva J.B., Fedosov V.E., Kozhin M.N., Ignatova E.A., Germano S.R., Golovina E.O., Gremmen N.J.M., Ion R., Stefanut S., Von Konrat M., Jimenez M.S., Suárez G.M., Kiebacher T., Lebouvier M., Long D.G., Maity D., Ochyra R., Parnikoza I., Plášek V., Fialová L., Skoupá Z., Poponessi S., Aleffi M., Sabovljević M.S., Sabovljević A.D., Saha P., Aziz M.N., Sawicki J., Suleiman M., Sun B.-Y., Váňa J., Wójcik T., Yoon Y.-J., Żarnowiec J. \& Larraín J. 2016. New national and regional bryophyte records, 46. Journal of Bryology 38(1): 47-63.
Hegedüšová K. \& Škodová I., (eds.), 2014, Vegetácia Slovenska. Rastlinné spoločenstvá Slovenska. 5. Travinnobylinná vegetácia [Vegetacion of Slovakia. Plant communities of Slovakia. 5. Grassland vegetation]. Slovak Akademy of Sciences, Bratislava.

Hultén E. \& Fries M., 1986, Atlas of North European vascular plants: north of the Tropic of Cancer, II. Koeltz Scientific Books, Königstein.

Kamiński D., Piernik A. \& Grobelski W., 2018, Morphological variability of Gentiana cruciata L. from different habitats, [in] 27th Congres of the European Vegetation Survey. 23-26 May, 2018 Wrocław, Poland. Vegetation survey 90 years after the publication of Braun-Blanquet's textbook - new challenges and concepts. Book of Abstracts. Botanical Garden University of Wrocław, Wrocław: 119.

Kaźmierczakowa R., 2004, Xerothermic grasslands and shrubs of the Pieniny National Park. Studia Naturae 49: 277-296.

Kaźmierczakowa R., Zarzycki J., Wróbel I. \& Vončina G., 2004, Meadows, pastures and wet habitat communities of the Pieniny National Park. Studia Naturae 49: 195-251.

Kéry M., Matthies D. \& Fischer M., 2001, The effect of plant population size on the interactions between the rare plant Gentiana cruciata and its specialized herbivore Maculinea rebeli. Journal of Ecology 89: 418-427.

Kleyer M., Bekker R.M., Knevel I.C., Bakker J.P, Thompson K., Sonnenschein M., Poschlod P., Van Groenendael J.M., Klimeš L., Klimešová J., Klotz S., Rusch G.M., Hermy M., Adriaens D., Boedeltje G., Bossuyt B., Dannemann A., Endels P., Götzenberger L., Hodgson J.G., Jackel A-K., Kühn I., Kunzmann D., Ozinga W.A., Römermann C., Stadler M., Schlegelmilch J., Steendam H.J., Tackenberg O., Wilmann B., Cornelissen J.H.C., Eriksson O., Garnier E. \& Peco B., 2008, The LEDA Traitbase: a database of life-history traits of Northwest European flora. Journal of Ecology 96: 1266-1274.

Kompała-Bąba A. \& Bąba W., 2013, The spontaneous succession in a sand-pit - the role of life history traits and species habitat preferences. Polish Journal of Ecology 61(1): 13-22.

Kondracki J., 2011, Geografia regionalna Polski [Regional geography of Poland]. PWN, Warszawa.

Kozuharova E.K., Anchev M.E. \& Popov P., 2005, The pollination ecology of Gentiana cruciata (Gentianaceae) - specifics of a Bulgarian population in comparision to Dutch populations. Nordic Journal of Botany 23(3): 365-372.

Kucharzyk S. \& Szary A., 2009, The non-forest vegetation of the Przemyskie Hills and the Słonne Mountains within the promotive complex of the „Birczańskie For- 
ests". Rocznik Przemyski, Nauki Przyrodnicze 45(5): 65-79.

Kucharzyk S., 2010, The xerothermic grassland with the snowdrop windflower Anemone sylvestris L. on the Przemyskie Foothills (SE Poland). Chrońmy Przyrodę Ojczystą 66(3): 190-200.

Matuszkiewicz W., 2001, Przewodnik do oznaczania zbiorowisk roślinnych Polski [A guide for identification of plant communities in Poland]. PWN, Warszawa.

Mirek Z., Piękoś-Mirkowa H., Zając A. \& Zając M., 2002, Flowering Plants and Pteridophytes of Poland. A Checklist. W. Szafer Institute of Botany, Polish Academy of Sciences, Kraków.

Ochyra R., Żarnowiec J. \& Bednarek-Ochyra H., 2003, Census catalogue of Polish mosses. W. Szafer Institute of Botany, Polish Academy of Sciences, Kraków.

Petanidou T., Nijs J.C.M. \& Oostermeijer J.G.B. 1995. Pollination ecology and constraints on seed set of the rare perennial Gentiana cruciata L. in The Netherlands. Acta Botanica Neerlandica 44(1): 55-74.

Piękoś-Mirkowa H. \& Mirek Z., 2006, Flora Polski. Rośliny chronione [Polish flora. Protected pants]. Multico Oficyna Wydawnicza, Warszawa.

Pielou E.C., 1974, Population and community ecology: principles and methods. CRC Press, New York.

Piotrowska J., 2010, Evaluation of preservation degree within selected populations of Gentiana cruciata in Western Pomerania. Folia Pomeranae Universitatis Technologiae Stetinensis 278(14): 57-74.

Rozporządzenie Ministra Środowiska z dnia 9 października 2014 w sprawie ochrony gatunkowej roślin (Dz.U. 2014 poz. 1409) [Regulation of the Minister of Environment of 9 October 2014 on the plant species protection], Warszawa.

Szczeblewska A. \& Janecki J., 1999, Xerothermic vegetation of the hills near Łuczyce and Jaksmanice in the vicinity of Przemyśl (Western Opole). Ochrona Przyrody 56: 79-89.

Towpasz K., 1987, The vascular plants of the Strzyżów Foothills. Zeszyty Naukowe Uniwersytetu Jagiellońskiego, Prace Botaniczne 16: 1-160.
Towpasz K., 1990, Geobotanical description of the Strzyżów Foothills. Zeszyty Naukowe Uniwersytetu Jagiellońskiego, Rozprawy habilitacyjne 178: 1-242.

Trąba C., Wolański P. \& Oklejewicz K., 2012, Communities with Brachypodium pinnatum and Bromus erectus in the Wiar and the San valleys. Annales Universitatis Mariae Curie-Skłodowska, Sectio C 67(1): 69-92.

Wójcik T., 2018, Occurrence of Gentiana cruciata (Gentianaceae) in a community with Brachypodium pinnatum (Festuco-Brometea) in Bukowa (Pogórze Strzyżowskie foothills). Fragmenta Floristica et Geobotanica Polonica 25(2): 205-215.

Wójcik T. \& Ochyra R., 2016, The first locality of the Ontario rose moss Rhodobryum ontariense in the Carpathian Foothills. Chrońmy Przyrodę Ojczystą 72(2): 130-140.

Wójcik T. \& Piątek K., 2015, New locality of Gentiana cruciata L. in the Strzyżowskie Foothills (Western Carpathians). Steciana 19(2): 67-73.

Wójcik T. \& Ziaja M., 2015, Plant communities of Kamieniec hill in Dynów Foothills (Western Carpathians). Parki Narodowe i Rezerwaty Przyrody 34(2): 57-74.

Zając A. \& Zając M., (eds), 2001, Distribution atlas of vascular plants in Poland. Laboratory of Computer Chorology, Institute of Botany, Jagiellonian University, Kraków.

Zając M. \& Zając A., 2009, The geographical element of native flora of Poland. Laboratory of Computer Chorology, Institute of Botany, Jagiellonian University, Kraków.

Zarzycki K., Trzcińska-Tacik H., Różański W., Szeląg Z., Wołek J. \& Korzeniak U., 2002, Ecological indicator values of vascular plants of Poland. W. Szafer Institute of Botany, Polish Academy of Sciences, Kraków.

Ziaja M. \& Wójcik T., 2014, Thermophilic plant communities in Natura 2000 site "Eąki nad Wojkówką" PLH 180051 - Podkarpacie Province. Annales Universitatis Mariae Curie-Skłodowska, Sectio C 69(1): 59-78. 



\title{
The vegetation of the cretaceous outcrops of Novhorod-Siverskyi Polesie loess "islands" (Ukraine) and the new locality of Gentiana cruciata L.
}

\author{
Oleksandr Lukash ${ }^{1, *}$, Iryna Miroshnyk ${ }^{2}$, Oleksandr Yakovenko ${ }^{1}$, Svitlana Strilets ${ }^{2}$
}

\begin{abstract}
${ }^{1}$ Department of Ecology and Nature Conservation, ${ }^{2}$ Department of Languages and Methodology,
T. Shevchenko National University "Chernihiv Collegium", Hetman Polubotko Str., 53, 14013, Chernihiv, Ukraine,

*e-mail: lukash2011@ukr.net
\end{abstract}

Received: 21 December 2018 / Accepted: 22 February 2019

\begin{abstract}
The vegetation of the cretaceous outcrops of Novhorod-Siverskyi Polesie loess "islands" is represented by the grasslands communities of the Artemisietea vulgaris Lohmeyer et al. in Tx. ex von Rochow1951, Festuco-Brometea Br.-Bl. et Tx. ex Soó 1947, Trifolio-Geranietea sanguinei T. Müller 1962 classes and shrubby phytocoenoses of the Robinietea Jurko ex Hadač et Sofron 1980 class. The structure and composition of the plant communities are influenced by the degree of anthropogenic influence (both in the past and present) on the ecosystems of cretaceous outcrops. The determining anthropogenic factors contributing to the formation of the ruderal communities were chalk mining and gardening. The influence of erosive processes is manifested in the spatial delimitation of plant communities of various syntaxonomic belongings. The anthropogenic successional communities: semiruderal grasslands and herblands of the immoral and subboreal zones of Europe (Convolvulo-Agropyretum repentis Felföldy (1942) 1943, Poo compressaeTussilaginetum farfarae R. Tx. 1931) and scrub communities of temperate Europe, represented by the Elytrigio repentis-Robinietum Smetana 2002 phytocoenoses typical for Steppe zones, prevail. Semixerothermic communities were found on the steep slopes of the cretaceous outcrops (eastern and southwestern expositions) - early successional stages with a significant amount of the characteristic species of the Festuco-Brometea Br.-Bl. et Tx. ex Soó 1947 class. On the cretaceous outcrops of Novhorod-Siverskyi Polesie loess "islands" the communities of Trifolion medii T. Müller 1962 (meso-subxerophytic fringe phytocoenoses on nutrient-poor but base-rich soils at lower altitudes of temperate Western and Central Europe) is localized on the slopes of the eastern and southeastern parts of the expositions which do not undergo anthropogenic influence and are separated by erosion forms. Such conditions were favorable for preserving the Gentiana cruciata L. relict species in this locality. The population of this species was found in the area of $50 \mathrm{~m}^{2}$ in the Trifolio medii-Agrimonietum Th. Müller 1962 association community and represented by two compact groups of individuals (the area of $0.5 \mathrm{~m}^{2}$ each) and individual plants. In order to preserve the habitat of this rare species, it is worth creating here a reserve.
\end{abstract}

Keywords: Polesie, cretaceous outcrops, loess "islands", plant communities, syntaxonomy, successional stages, rare plant species, anthropogenic impact.

\section{Introduction}

Among other Polesie districts, Novhorod-Siverskyi Polesie is characterized by the considerable dismemberment and outcrop of indigenous sediments. This imposes an imprint on the vegetation cover of the territory. The ecological and phytoindicative study of the plant communities of cretaceous outcrops of the Desna River right bank was carried out in the outskirts of the Kamin, Pushkari, Rohivka villages of the Novhorod-Siverskyi district, Chernihiv region (Savon \& Lysenko, 2001). Our research covered the area located to the south of the earlier studies: in the 
outskirts of the Putyvsk, Yukhnove and Horky villages. The goal of our study was to determine the composition of plant communities of cretaceous outcrops of NovhorodSiverskyi Polesie, to find out their syntaxonomic affiliation and floristic features. The working hypotheses of the research: the cretaceous outcrops of Novhorod-Siverskyi Polesie are the potential places of formation of the xerothermic and semixerothermic grass communities and the habitats of rare plant species, characterizing these communities. One of such species is Gentiana cruciata L. - the object of the population modelling the spatial interactions between plants and insects (Clarke et al., 1998).

\section{Study area}

The investigated area (Fig. 1A) covers the zone with the largest dismemberment and and outcrop of root sediments along the right bank of the meridial part of the Desna River with the outcrops of indigenous sediments from the right bank of the lower part of the Sudost river to the turn of the Desna River to the southwest. The Desna River valley and its right bank tributaries, gullies, ravines cut the whole thickness of anthropogenic and paleogene sediments and penetrate deeply into the thickness of cretaceous sediments. In the thickness of cretaceous sediments in the right bank of the slopes of the Desna valley dark gray marls, limestone glauconitic sands and white chalk are outcropped. The surface of cretaceous sediments carries the marks of intense erosive dismemberment. The variation of absolute marks is from 125 to $165 \mathrm{~m}$ (Marynich, 1968).

In some parts paleogene sediments are partially blurred and anthropogenic sediments lie directly on chalky rocks. The lower layer of the anthropogenic strata is moraine. Moraine often lays the slopes of the right tributaries of the Desna River and its large gullies. The valleys of the right bank tributaries of the Desna River divide the explored area into several loess "islands": Rohovskyi, NovhorodSiverskyi, Blystovitskyi, Ponornytskyi. The last ones are the continuation of the loess "islands" of Chernihiv Polesie, which are characterized by a greater degree of synanthropy of the vegetation cover (Lukash et al., 2018).

In the hypsometric plane, the territory is an elevated plain, absolute markings of which exceed $200 \mathrm{~m}$. The ex-

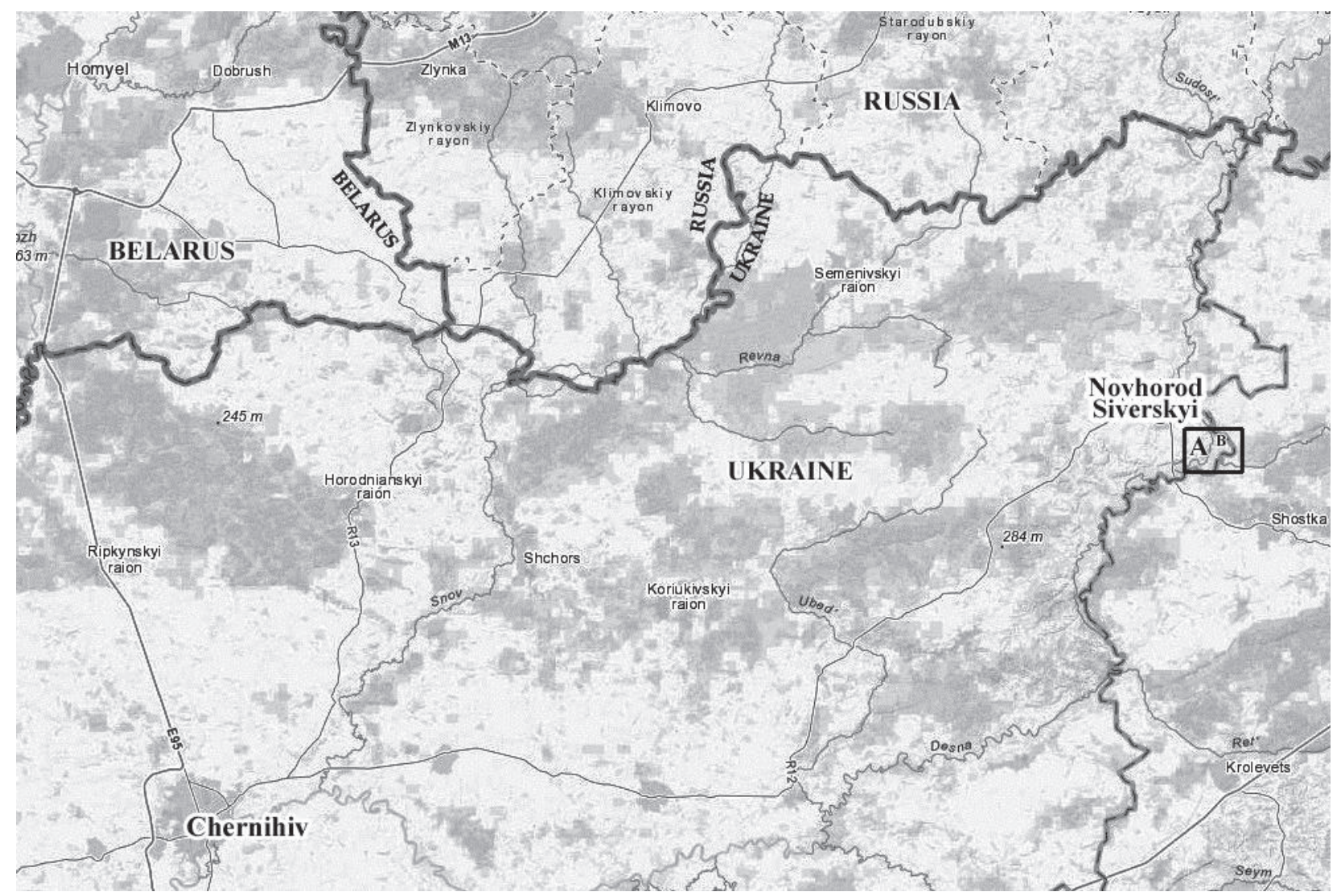

Figure 1. Location of the cretaceous outcrops of Novhorod-Siverskyi Polesie loess "islands" (the square marked as "A") 
cess of the Desna is $100-105 \mathrm{~m}$. The proximity of the deep local base of erosion and the fact that the loess cover is easily eroded is the main cause of the exclusive development of the ravine and gully network, the density of which exceeds $1 \mathrm{~km} / \mathrm{km}^{2}$. The meadow-steppe and synanthropic vegetation is well represented on the slopes of the ravines and gullies.

\section{Material and methods}

The materials for the article were collected during the field research of the loess "islands" of Novhorod-Siverskyi Polesie during 2006-2018. The field study of the vegetation was carried out by geobotanical methods (Korchahin, 2012). The vegetation descriptions were carried out during theoptimum of vegetation period in the areas of $30-50 \mathrm{~m}^{2}$. The exposition and steepness of the slopes, the general projective coverage of the vegetation community and the coverage of each species were noted Cover abundance scale is the following: + - up to $1 \%, 1-1-5 \%, 2-6-15$, $3-16-25 \%, 4-26-50 \%, 5>50 \%$. 25 phytosociological relevés were taken. Syntaxa were identified according to Mucina et al. (2016), Matuszkiewicz (2001) (for natural vegetation), Solomakha et al. (1992) (for synanthropic vegetation), Brzeg (2005) (for Trifolio-Geranietea sanguinei communities). Syntaxa names are ordered according to Mucina et al. (2016). The successional stages of vegetation are named by the dominant species.

\section{Results and discussion}

A generalized scheme of the vegetation of the cretaceous outcrops of Novhorod-Siverskyi Polesie loess "islands" is the following:

Class: Artemisietea vulgaris Lohmeyer et al. in Tx. ex von Rochow1951

Order: Agropyretalia intermedio-repentis T. Müller et Görs 1969
The group of semiruderal alliances

Alliance:Convolvulo arvensis-Agropyrion repentis Göors 1967

Association: Convolvulo-Agropyretum repentis Felföldy (1942) 1943

Association: Falcario vulgaris-Agropyretum repentis Müller et Görs 1969

Association: Poo compressae-Tussilaginetum farfarae R. Tx. 1931

Class: Festuco-Brometea Br.-Bl. et Tx. ex Soó 1947

The group of orders of sub-xeric steppic grasslands

Order: Brachypodietalia pinnati Korneck 1974

Iinitial community: Chamaecytisus ruthenicus-Aster amellus [Cirsio-Brachypodion pinnati Hadač et Klika in Klika et Hadač 1944 + Molinio-Arrhenatheretea Tx. 1937+Trifolio-Geranietea sanguinei T. Müller 1962]

Iinitial community Elytrigia intermedia-Salvia pratensis [Cirsio-Brachypodion pinnati Hadač et Klika in Klika et Hadač 1944 + Molinio-Arrhenatheretea Tx. 1937 + Trifolio-Geranietea sanguinei T. Müller 1962]

Initial community Origanum vulgare purum [CirsioBrachypodion pinnati Hadač et Klika in Klika et Hadač $1944+$ Molinio-Arrhenatheretea Tx. $1937+$ Trifolio-Geranietea sanguinei $\mathrm{T}$. Müller 1962]

Class: Trifolio-Geranietea sanguinei T. Müller 1962

Order: Origanetalia T. Müller 1962

Alliance: Trifolion medii T. Müller 1962

Association: Trifolio medii-Agrimonietum Th. Müller 1962

Class: Robinietea Jurko ex Hadač et Sofron 1980

Order: Chelidonio-Robinietalia Hadač et Sofron 1980

Alliance: Balloto nigrae-Robinion pseudoacaciae Hadač et Sofron 1980

Association: Elytrigio repentis-Robinietum Smetana 2002.

Relevés 1-14 (Table 1) belong to the Convolvulo arvensis-Agropyrion repentis association from the Agropyretalia intermedio-repentis order of the Artemisietea vulgaris class. The cenoses of the Convolvulo-Agropyretum repentis association occupy the largest areas on the cretaceous sediments (Fig. 2B). 


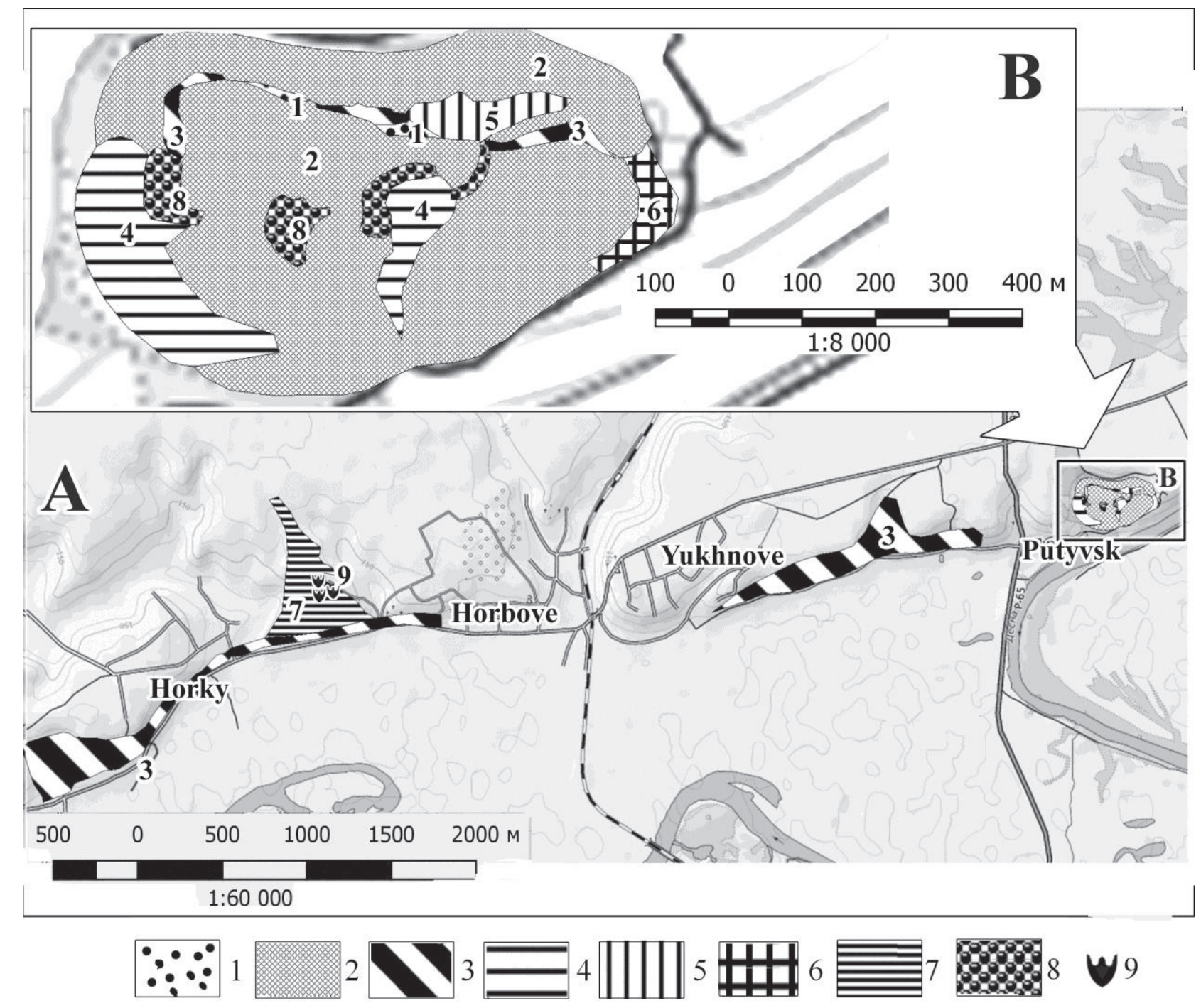

Figure 2. Mapping of the vegetation of the cretaceous outcrops of Novhorod-Siverskyi Polesie loess "islands". Syntaxon (1-8): 1 - Falcario vulgaris - Agropyretum repentis, 2 - Convolvulo arvensis - Agropyretum repentis, 3 - Poo compressae-Tussilaginetum farfarae, 4 - Chamaecytisus ruthenicus - Aster amellus, 5-Elytrigia intermedia-Salvia pratensis, 6 - Origanum vulgare purum, 7 - Trifolio medii-Agrimonietum, 8 - Elytrigio repentis-Robinietum; 9 - the habitat of Gentiana cruciata L. 


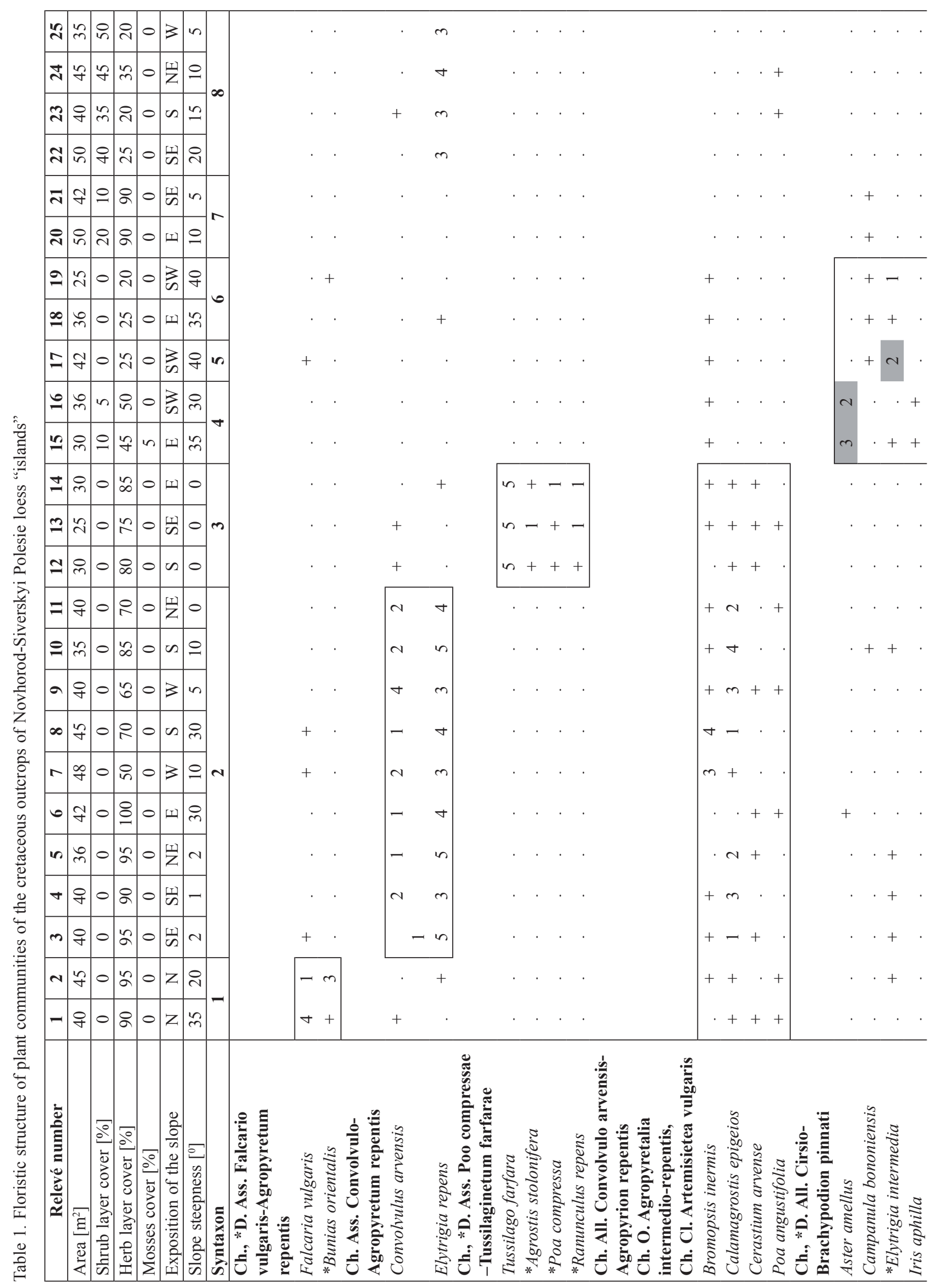



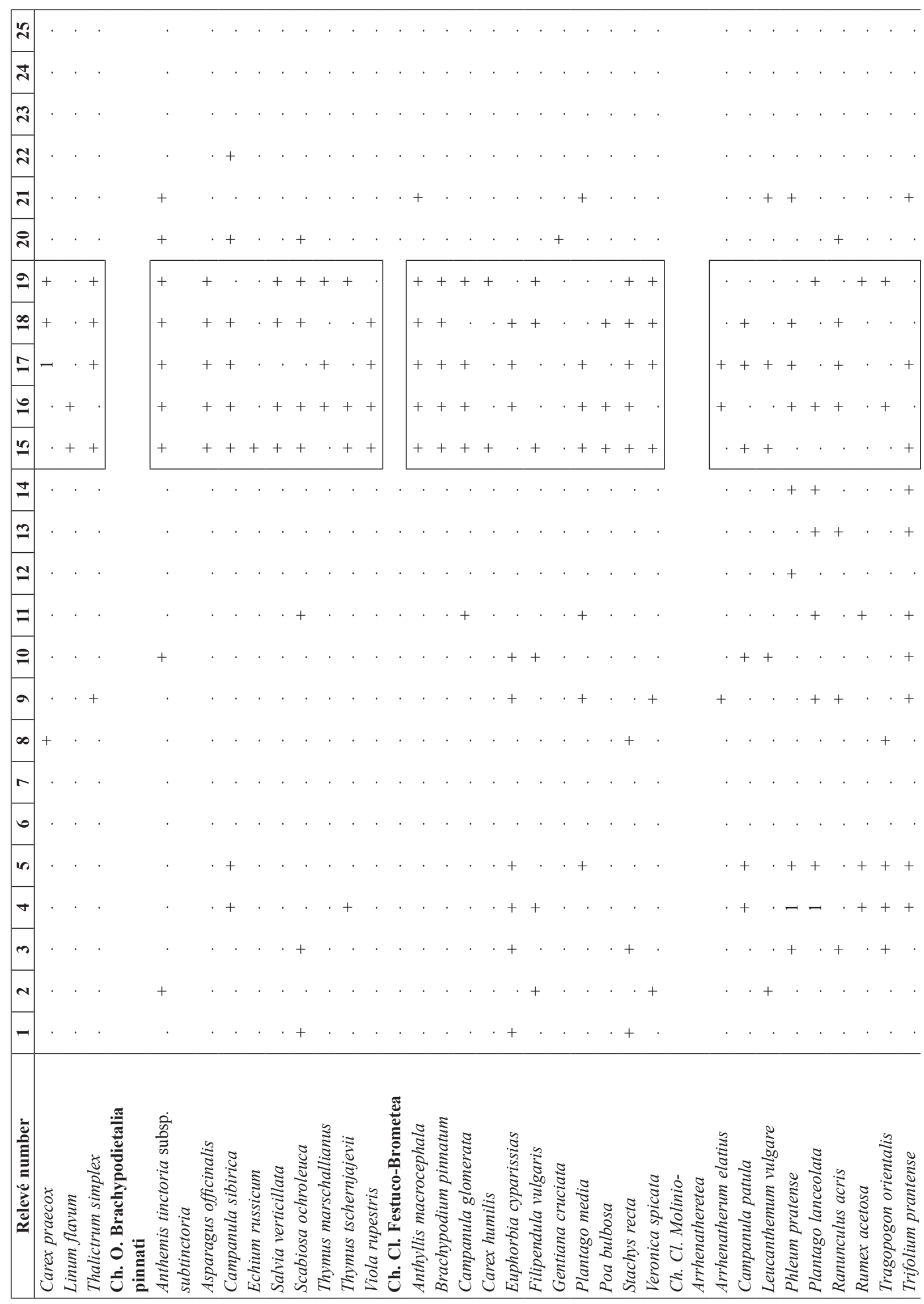


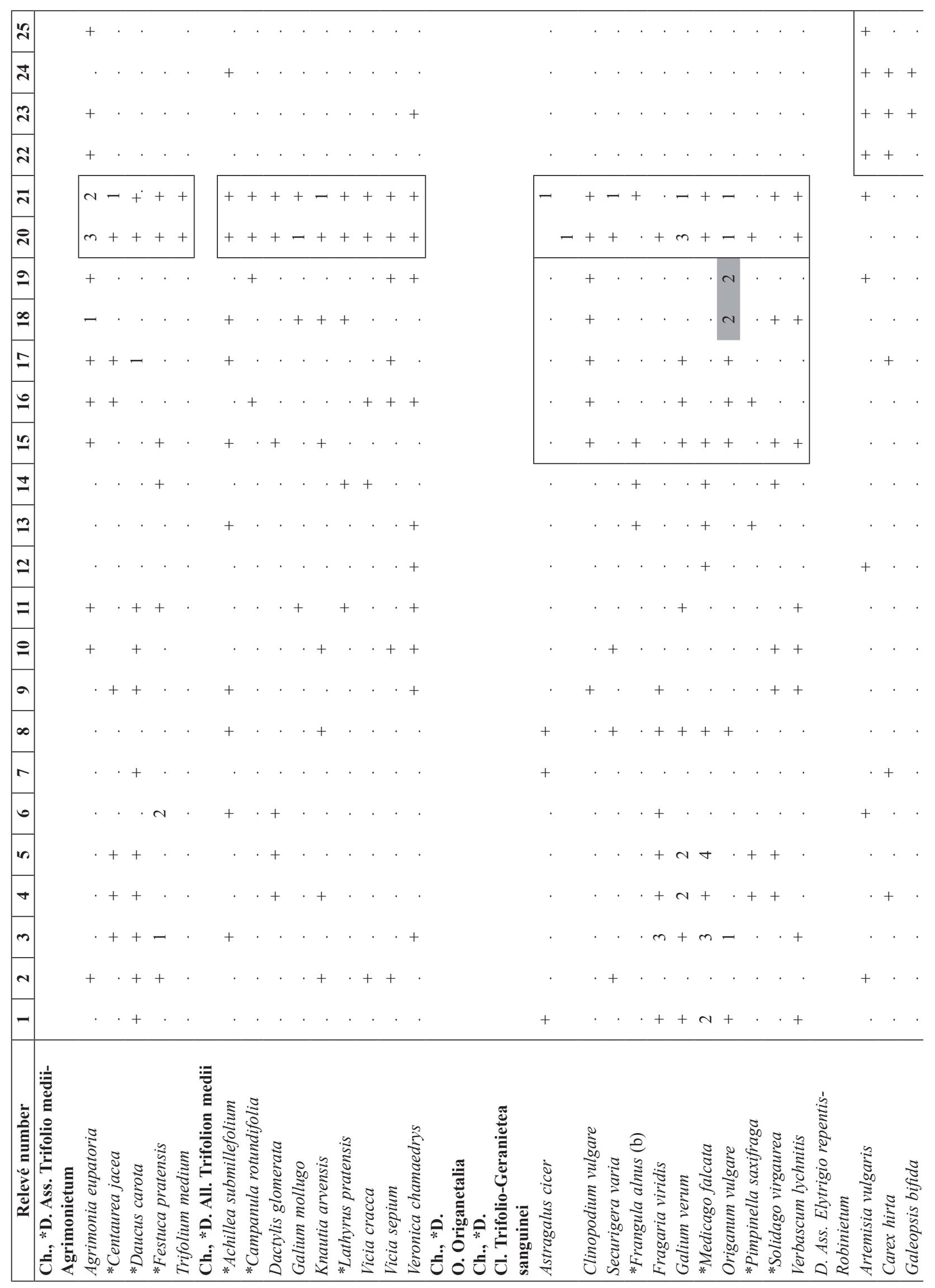




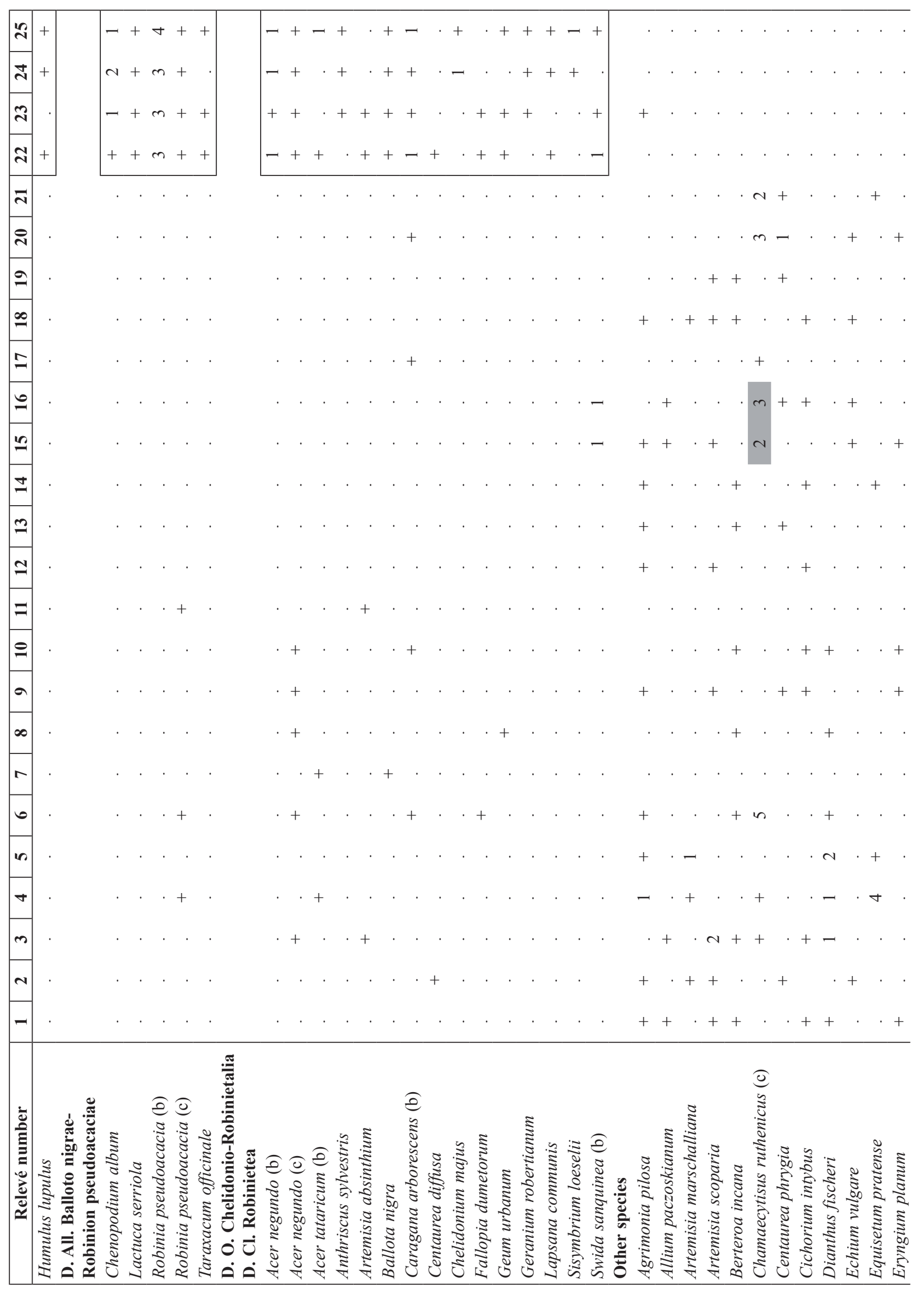




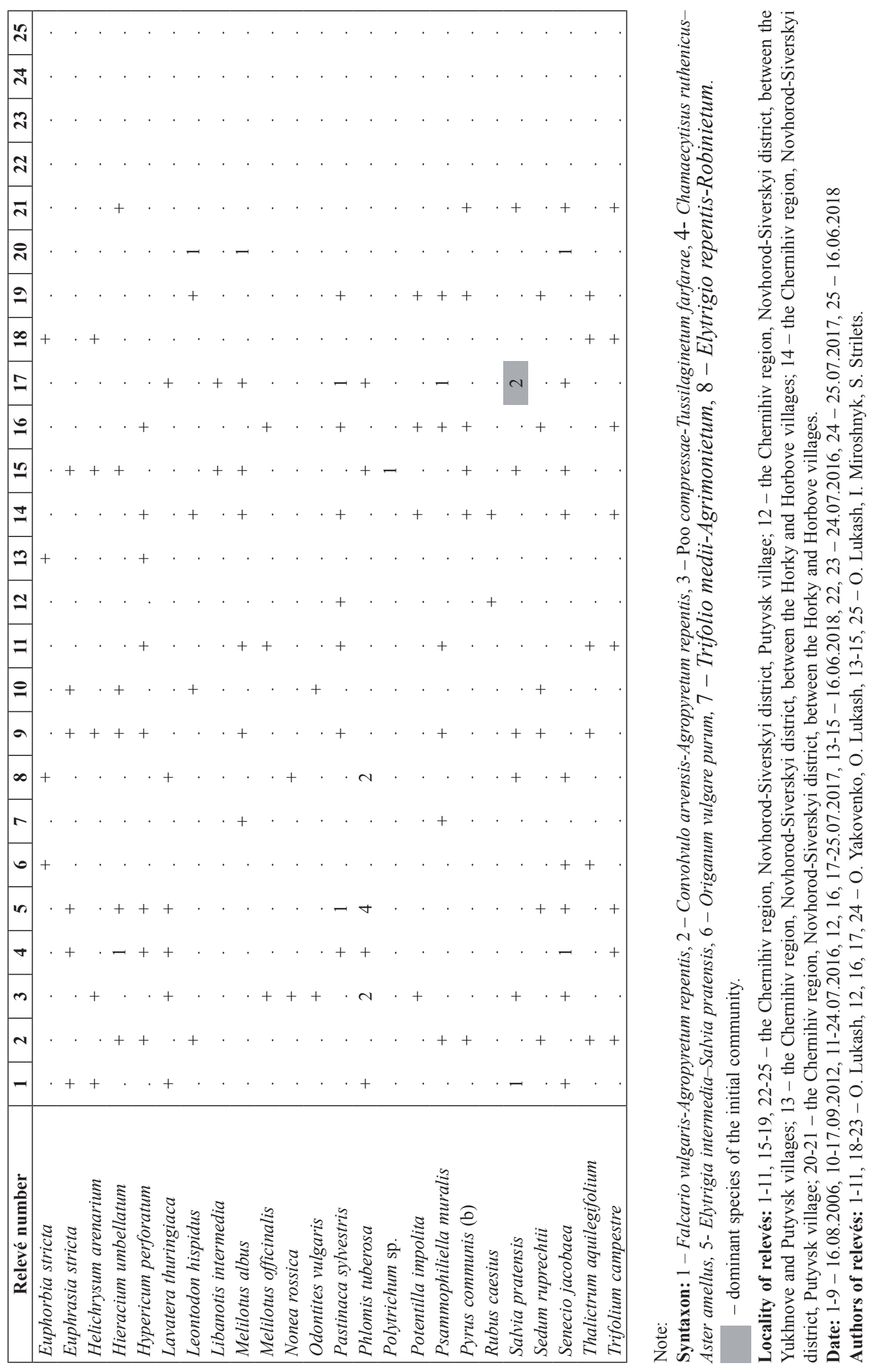


The Convolvulo-Agropyretum repentis phytocoenoses were formed in the areas covered with a $0.5-1.0$-meter layer of loess sediments. These areas were used by the locals 20-25 years ago as kitchen gardens, and now they are experienced such types of anthropogenic influence as cattle grazing and recreational load. The communities are formed by such species as Elytrigia repens (L.) Nevski and Convolvulus arvensis L., sometimes Calamagrostis epigeios (L.) Roth. co-predominates, Cerastium arvense L., Elytrigia intermedia, Poa angustifolia L., P. compressa L. Bromopsis inermis (Leyss.) Holub are singly found. The species of the Molinio-Arrhenatheretea and Festuco-Brometea classes take part in this association communities formation.

Consequently, the Convolvulo-Agropyretum repentis ruderal communities described by us, which are characterized by a high participation of biennial or perennial plants, are mostly a succession stage, which is replaced by the community of Sisymbrion officinalis (Class Papaveretea rhoeadis).

The communities, belonging to the Falcario vulgaris-Agropyretum repentis association, occur on the northern slopes near the Putyvsk village (Fig. 2B). These phytocoenoses occupy small "islets" between erosive dams. They are diagnosed by the dominant species of Falcaria vulgaris Bernh. and Bunias orientalis L.

The foot of cretaceous outcrops is occupied by the phytocoenoses belonging to the Poo compressae-Tussilaginetum association (Fig. 2A, B; Table 1, relevés 12-14). As a rule they were formed in the places of industrial and spontaneous mining of chalk. It should be noted that industrial mining of chalk was carried out near the Putyvsk village in the 70's-90's years of the twentieth century. Unauthorized local chalk mining is continued to the present time. Tussilago farfara L. (the characteristic species of the association) dominates in all of the described areas. These communities are also differentiated by Agrostis stolonifera L., Poa compressa L. and Ranunculus repens L. Depending on the time of phytocoenoses formation the areas of the Poo compressae-Tussilaginetum association vary by the number of species. In the areas, where industrial mining of chalk stopped 30 years ago (Table 1, relevé 14), 34 species were recorded, among which rhizome perennials predominate, as well as tree and shrub species (on the level of the grassy tier).

In the absence of anthropogenic pressure, grass communities with traits of steppe phytocoenoses were formed on the steep slopes of the cretaceous outcrops of the eastern and southwest expositions (Fig. 2B; Table 1, relevés 15-19). This is evidenced by the presence of the characteristic species of the Festuco-Brometea class in the described areas, Anthyllis macrocephala Wender, Brachypodium pinnatum (Huds.) P.Beauv., Campanula glomerata L., Carex humilis Leyss., Euphorbia cyparissias L., Filipendula vulgaris Moench, Plantago media L., Poa bulbosa L., Poa compressa L., Stachys recta L., Veronica spicata L. in particular. There are the characteristic species of the Brachypodietalia pinnati order and the Cirsio-Brachypodion pinnati alliance in all the five relevés. However, the structure and (or) composition of the described communities does not allow to clearly refer them to one or another association of the alliance mentioned above. Note that there is a number of species according to which the Molinio-Arrhenatheretea and Trifolio-Geranietea sanguinei classes are diagnosed in relevés 15-19. Probably the phytocoenoses described by us are the communities at early stages of successions with domination of Chamaecytisus ruthenicus (Fisch. Ex Woł.) Klásková and Aster amellus L. (relevés 15-16), Elytrigia intermedia (Host) Nevski and Salvia pratensis L. (relevé 17), as well as Origanum vulgare L. (relevés 18-19). A projective coverage of the dominants is $15-25 \%$ with a total projective cover of $20-50 \%$. As part of these communities, there is a number of rare for Polesie species that are situated in this region on the northern border of distribution. For example: Aster amellus L., Carex praecox Schreb, Echium russicum J.F. Gmel, Iris aphilla L. and Linum flavum L., Salvia verticillata L., Phlomis tuberosa L. and others. Thus, the recorded xerothermophilic communities have an environmental significance and are the objects of monitoring researches.

Xerothermic and semixerothermic steppe communities in Polesie are rare. For the Western Polesie within the borders of Belarus, Poland and Ukraine (Fijałkowski et al., 2002), as well as the "Prybuzhskoe Polesie" Biosphere Reserve (Demyanchik, 2006), the presence of xerothermic grass communities of the Festuco-Brometea class on the cretaceous sediments is indicated. Such communities are not mentioned for the Polesie National Park (Baryla et al., 2002; Święs, 2002) and Polesie Natural Reserve (Vorobyov et al., 1997). Within Ukrainian (Southern) Polesie the Festuco-Brometea steppe communities are known in Zhytomyr Polesie near the rivers, where crystalline sediments are lying off (Onishchenko, 2006). But they have not been studied in detail. The communities of the Festuco-Brometea class in the Briansk region (Russia) within the boundaries of the loess plateau landscapes in the western spurs of the Middle Russian Highlands, where they are on the northern border of their habitat (Bulokhov, 2001, 2009) have been investigated to the greatest extent. Within Eastern Polesie these are the closest xerothermic phytocoenoses in the cretaceous sediments to the communities described by us. On the territory of the Briansk region, in the composition of the Festuco-Brometea class one Festucetalia valesiacae Soó 1947 order, Cirsio-Brachypodion pinnati Hadač et Klika in Klika et Hadač 1944 alliance with one Poo compressae-Onobrychidoetum arenariae Bulokhov 1990 association (Bulokhov, 2001) was established. The diagnostic species of this 
association are Onobrychis arenaria (Kit.) DC. and Poa compressa $\mathrm{L}$. The communities of this association can be found in small sections on the steep eroded slopes of river valleys and gullies on the complex of ravine-gully gray forest soils spread by chalk. The comparison of phytocoenotic data makes it possible to note that the communities described by A. Bulokhov $(2001,2009)$ differ from the xerothermic phytocoenoses on the cretaceous sediments of Novhorod-Siverskyi Polesie with a greater representation of steppe species.

In relevés 20 and 21 (Table 1), taked out at the chalk outcrops near the Horky village, the characteristic species (Astragalus cicer L., Clinopodium vulgare L., Securigera varia (L.) Lassen, Origanum vulgare, Verbascum lychnitis L.) and diagnostic species (Frangula alnus Mill., Medicago falcata L., Pimpinella saxifraga L.., Solidago virgaurea L.) of the Trifolio-Geranietea class and the Origanetalia order were identified. The described community is referred to the Trifolion medii alliance due to the presence of a number of diagnostic species, among which are the species of the specified alliance: Agrimonia eupatoria L., Galium mollugo L., Trifolium medium L., Vicia sepium L., and the typical species of the Molinio-Arrhenatheretea class (Achillea submillefolium Klokov et Krytzka, Campanula rotundifolia L., Dactylis glomerata L., Knautia arvensis (L.) Coult., Lathyrus pratensis L., Veronica chamaedrys L., Vicia cracca L. et al.). Its belonging to the group of the neutrophilic associations shows the presence of Geranium sylvaticum, Medicago falcata L., Securigera varia. A. Brzeg (2005) points out the characteristic (Agrimonia eupatoria, Trifolium medium L.) and differential (Centaurea jacea L., Daucus carota L., Festuca pratensis Huds. \& Potentilla reptans L.) species for the Trifolio medii-Agrimonietum association. All these species, except the last one, were recorded in the phytocoenoses described by us. That is why we referred these communities from relevés 20 and 21 to the specified association.

In the outskirts of the Putyvsk village on the slopes of the cretaceous outcrops scrub communities of temperate Europe, represented by non-typical for Polesie synanthropic Elytrigio repentis-Robinietum phytocenoses, which are characteristic of the Steppe zone of Ukraine, were formed (Fig. 2B; Table 1, relevés 22-25). These communities are formed by Robinia pseudoacacia L. (3-4 m high) with an admixture of Acer negundo L. The reason for referring the identified communities to the corresponding association is the presence of the diagnostic species (Chenopodium album L., Lactuca serriola L., Taraxacum officinale Wigg. Aggr.) of the Balloto nigrae-Robinion pseudoacaciae Hadač et Sofron 1980 association and the diagnostic species (Elytrigia repens (L.) Nevski with a $20-40 \%$ projective covering, as well as Artemisia vulgaris L., Carex hirta L., Galeopsis bifida Boenn. Humulus lupulus L.) of the Elytrigio repentis-Robinietum association.
We believe that the Elytrigio repentis-Robinietum phytocoenoses are the last stage of the overgrowth of the cretaceous outcrops slopes in the succession series: ruderal phytocenoses of nutrient-demanding short-lived winter annual grasses on sandy anthropogenic soils (Sisymbrion officinalis Tx. et al. ex von Rochow 1951) $\rightarrow$ semiruderal grasslands and herblands (Convolvulo-Agropyretum repentis Felföldy (1942) 1943) $\rightarrow$ ruderal shrub communities Elytrigio repentis-Robinietum Smetana 2002).

In chalk outcrops in the community of the Trifolio medii-Agrimonietum association in the area of $50 \mathrm{~m}^{2}$ (Fig. 2A; Table1, relevé 20) the Gentiana cruciata population was determined. The middle density of the population was 0.34 individuals $/ \mathrm{m}^{2}$. It is represented by two compact groups of 3 and 4 generative individuals, the area of $0.5 \mathrm{~m}^{2}$ each, and 10 juvenile individual plants. The plants of other ontogenetic states have not been found. Thus, the population of $G$. cruciata in a new locality can be characterized as incompletely limbed with a left-sided spectrum: juvenile plants predominate. In Fig. 3 the spatial structure of the $G$. cruciata population is represented.

G. cruciata - a European-Southwest Asian foreststeppe relict species, included in the Red Books of the Republic of Belarus (Skuratovich, 2015) and the Briansk region (Evstigneev, 2004). This species is very rare for the Eastern Polesie. The nearest to the identified place is the "Markovsk mountains" (the Briansk region) - the richest in the Eastern Polesie center of the calcephalous flora. For today, our discovery of G. cruciata is the first and only one for Novhorod-Siverskyi Polesie. It should be noted, that G. cruciata is a diagnostic species of the FestucoBrometea Br.-Bl et Tx. ex Soó 1947 class. However, the conditions of the determined location (open slope of the eastern exposition, close occurrence of carbonate rocks) are typical for the location of this species. For comparison, in Western Europe (in particular, in Poland), the locations of $G$. cruciata were found in xerothermic grassland on the southern and south-western slopes of the river valleys in the communities that are characterized by high proportions of species of the Festuco-Brometea, MolinioArrhenatheretea, Trifolio-Geranietea sanguinei and Rhamno-Prunetea classes (Wójcik \& Piątek, 2015, Wójcik, 2018). In Western Pomerania the population of this species was found in Adonido-Brachypodietum pinnati communities for which $G$. cruciata is a characteristic species (Piotrowska, 2010). It is worth noting that the populations of G. cruciata in western localities, in comparison with the populations in Novhorod-Siverskyi Polesie, are larger in size, more numerous and denser. For example, in Brwice population 183 individuals of G. cruciata were found in the area $1200 \mathrm{~m}^{2}$ (Piotrowska, 2010). 1107 individuals of $G$. cruciata were found in Unisław locality, the highest frequency and density was 0.339 individuals $/ \mathrm{m}^{2}$ (KrasickaKorczyńska et al., 2011) 


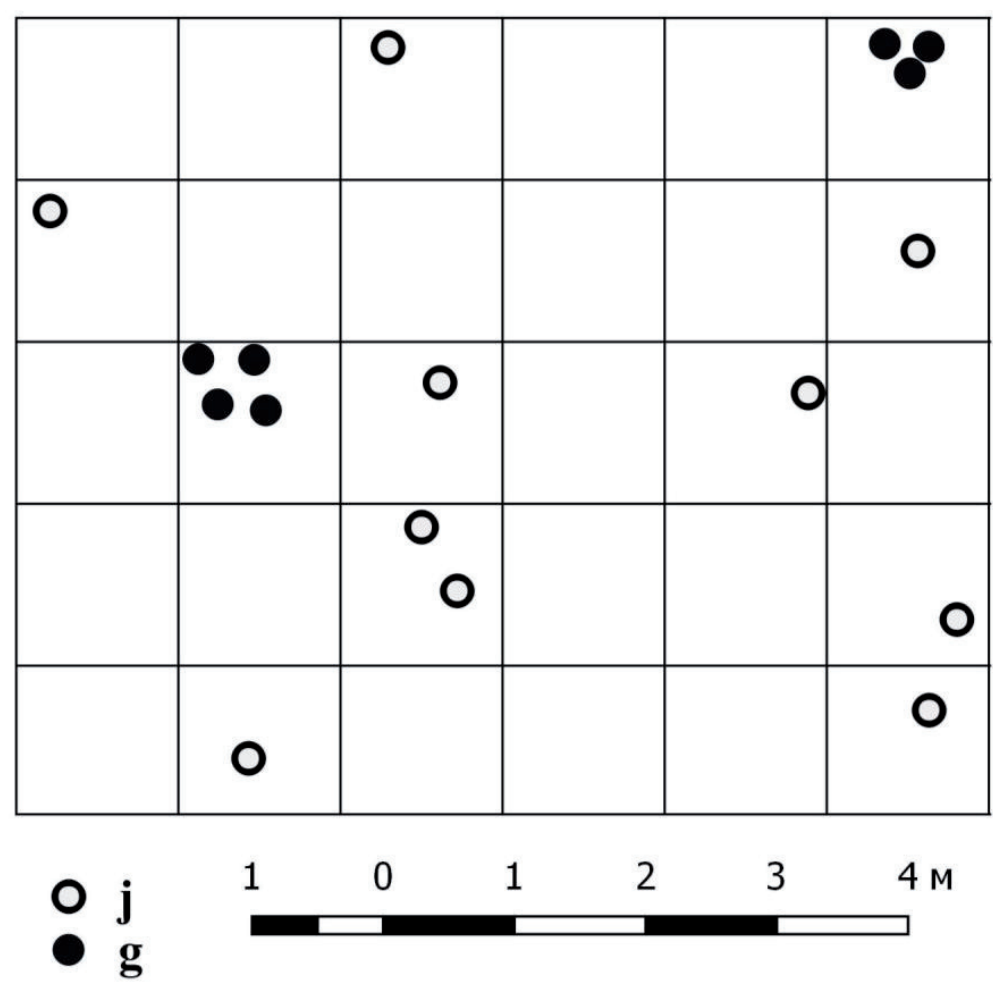

Figure 3. Spatial structure of the G. cruciata population in the Novhorod-Siverskyi locality. Denotations: j - juvenile individuals, $\mathrm{g}$ - generative individuals

The G. cruciata locality in Novgorod-Siverskyi Polesie loess "islands" is not under conservation. Therefore, in order to preserve the habitat of this rare species, it is worth creating here a reserve.

\section{Conclusions}

The structure and composition of the vegetation communities of the cretaceous outcrops of Novhorod-Siverskyi Polesie loess "islands" is influenced by the degree of anthropogenic influence (both in the past and present) on the ecosystems. The determining anthropogenic factors contributing to the formation of the ruderal communities were chalk mining and gardening. The influence of erosive processes is manifested in the spatial delimitation of plant communities of various syntaxonomic belongings.

In the vegetation cover of the cretaceous outcrops of Novhorod-Siverskyi Polesie loess "islands" semiruderal grasslands and herblands phytocoenoses of the nemoral and subboreal zones of Europe belonging to the Convolvulo arvensis-Agropyrion repentis Göors 1967 association predominate. The Elytrigio repentis-Robinietum Smetana 2002 phytocenoses is the last stage of the overgrowth of the cretaceous outcrops slopes during the succession from the ruderal vegetation of nutrient-demanding short-lived winter annual grasses on sandy anthropogenic soils to Robinia groves with weedy understorey on loamy dry soils.

The initial semixerothermic communities (Chamaecytisus ruthenicus-Aster amellus, Elytrigia intermediaSalvia pratensis, Origanum vulgare purum) are close to the phytocoenoses of the Festuco-Brometea class by the species composition. Natural meso-subxerophytic fringe vegetation on nutrient-poor but base-rich soils (Trifolion medii T. Müller 1962) are represented fragmentarily. They do not suffer from the anthropogenic pressure and are separated by erosive forms. Such conditions were favorable for preserving the relict Gentiana cruciata L. species in this locality. The population of this species was found in the area of $50 \mathrm{~m}^{2}$ in the community of the Trifolio medii-Agrimonietum Th. Müller 1962 association and represented by two compact groups of individuals (the area of $0.5 \mathrm{~m}^{2}$ each) and individual plants. In order to preserve the habitat of this rare species, it is worth creating here a reserve. 


\section{References}

Baryła R. \& Urban D., 2002, Ekosystemy łąkowe [Meadow ecosystems], [in:] S. Radwana (ed.), Poleski Park Narodowy [Polesie National Park]. Wydawnictwo MORPOL, Lublin: 201-215.

Brzeg A., 2005, Zespoły kserotermofilnych ziołorośli okrajkowych z klasy Trifolio-Geranietea sanguinei Th. Müller $1962 \mathrm{w}$ Polsce [Xerothermophilous forb fringes and forest edge communities of the class Trifolio-Geranietea sanguinei Th. Müller 1962 in Poland]. Bogucki Wydawnictwo Naukowe, Poznań.

Bulokhov A.D., 2001, Grass vegetation of the South-Western Non-Black Earth Region of Russia. Publishing House of Bryansk State University, Bryansk.

Bulokhov A.D., 2009, Typology of meadows of the Bryansk region. Publishing House of Bryansk State University, Bryansk.

Clarke R.T., Thomas J.A., Elmes G.W., Wardlaw J.C., Munguira M.L. \& Hochberg M.E., 1998, Population modelling of the spatial interactions between Maculinea rebeli their initial foodplant Gentiana cruciata and Myrmica ants within a site. Journal of Insect Conservation 2(1): 29-37.

Demyanchik V.T., 2006, "Pribuzhskoye Polesie" Biosphere Reserve, I.I. Lishtvan (ed.). PH Academy, Brest.

Evstigneev O.I., 2004, Gentiana cruciata L., [in:] Yu.P. Fedotov (ed.), The Red Book of the Bryansk region. Plants. Mushrooms. Chitay-gorod, Bryansk: 201-202

Fijałkowski D., Andrienko T., Onyszenko W., Święs F. \& Urban D., 2002, Ekosystemy lądowe - leśne, kserotermiczne i synantropijne Polesia (Flora i fitocenozy) [Terrestrial and forest, xerothermic, and synanthropic ecosystems of Polesie (Flora and phytocoenoses)]. Acta Agrophysica 66: 147-177.

Krasicka-Korczyńska E., Stosik T. \& Kwiatkowska B., 2011, Zasoby populacji Gentiana cruciata L. na przykładzie murawy kserotermicznej w Unisławiu [Resources of Gentiana cruciata L. population of kerothermic grasslands in Unisław]. Ekologia i Technika 19(6): 333-339.

Korchagin A.A., 2012, Field geobotany. Methodical guidance. E.M. Lavrenko (ed.). PH Ozon.ru, Moscow.

Lukash O., Yakovenko O. \& Miroshnyk I., 2018, The mechanical degradation of land surface and the present state of the loess "islands" plant cover of Chernihiv Polesie (Ukraine). Ecological Questions 29(4): 23-34.

Matuszkiewicz W., 2001, Przewodnik do oznaczania zbiorowisk roślinnych Polski [Guide for determination of Polish plant communities]. Wydawnictwo Naukowe PWN, Warszawa.

Mucina L., Büultmann H., Dierßen K., Theurillat J.-P., Raus T., Čarni A., Šumberová K., Willner W., Dengler J., García R.G., Chytrý M., Hájek M., Di Pietro R., Iakushenko D., Pallas J., Daniëls F.J.A., Bergmeier E.,
Guerra A.S., Ermakov N., Valachovič M., Schaminće J. H.J., Lysenko T., Didukh Y.P., Pignatti S., Rodwell J.S., Capelo J., Weber H.E., Solomeshch A., Dimopoulos P., Aguiar C., Hennekens S.M.\& Tichý L., 2016, Vegetation of Europe: hierarchical floristic classification system of vascular plant, bryophyte, lichen, and algal communities. Applied Vegetation Science 19 (S1): 3-264. (https:// onlinelibrary.wiley.com/doi/epdf/10.1111/avsc.12257).

Marynich A.M. (ed.), 1968, Physical and geographical zoning of the Ukrainian SSR. Publishing House of Kiev University, Kiev.

Onischenko V.A., 2006, Floristic classification of the Ukrainian Polesie vegetation. [in:] T.L. Andrienko (ed.), Phytodiversity of the Ukrainian Polesie and its conservation. Phytosociocentre, Kyiv: 43-84.

Piotrowska J., 2010, Ocena stanu zachowania wybranych populacji goryczki krzyśowej (Gentiana cruciata) na Pomorzu Zachodnim [Evaluation of preservation degree within selected populations of Gentiana cruciata in Western Pomerania]. Folia Pomeranae Universitatis Technologiae Stetinensis, Agric., Aliment., Pisc., Zootech. 278(14): 57-74.

Savon A.P. \& Lysenko H.M., 2001, Ecological and phytoindicative characteristic of plant communities of cretaceous outcrops of Novhorod-Siverskyi Polesie. Ecological state of the Chernihiv region and ways of its optimization: materials of the inter-university student's conference, June 2, 2001. Chernihiv: 21-22.

Skuratovich A.N., 2015, Gentiana cruciata L., [in:] I.M. Kachanovsky, M.E. Nikiforov, V.I. Parfenov (eds), The Red Book of the Republic of Belarus. Plants. Petrus Brovka Belorussian Encyclopedia, Minsk: 184-185.

Solomakha V.A., Kostylov O.V. \& Sheliah-Sosonko Yu.R., 1992, Synanthropic vegetation of Ukraine. Scientific thought, Kyiv.

Święs F., 2002, Ekosystemy synantropijne [Synanthropic ecosystems], [in:] S. Radwana (ed.), Poleski Park Narodowy [Polesie National Park]. Wydawnictwo MORPOL, Lublin: 216-230.

Vorobyov Ye.O., Balashov L.S. \& Solomakha V.A., 1997, The syntaxonomy of vegetation of the Polesie Natural Reserve. Ukrainian Phytosociologocal Collection 8(1): 6-127.

Wójcik T., 2018, Występowanie Gentiana cruciata (Gentianaceae) w zbiorowisku z Brachypodium pinnatum (Festuco-Brometea) w Bukowej na Pogórzu Strzyżowskim [Occurrence of Gentiana cruciata (Gentianaceae) in a community with Brachypo-dium pinnatum (Festuco-Brometea) in Bukowa (Pogórze Strzyżowskie foothills)]. Fragmenta Floristica et Geobotanica Polonica 25(2): 205-215.

Wójcik T. \& Piątek K., 2015, New locality of Gentiana cruciata L. in the Strzyżowskie Foothills (Western Carpathians). Steciana 19(2): 67-73. 